\title{
Artelogie
}

artelogie Recherche sur les arts, le patrimoine et la littérature de l'Amérique latine

$6 \mid 2014$

Horizons et dispositifs des arts plastiques des pays du Río de la Plata (XXe siècle)

\section{Arte, memoria y derechos humanos en Argentina}

\section{Andrea Giunta}

\section{OpenEdition}

\section{Journals}

Edición electrónica

URL: http://journals.openedition.org/artelogie/1420

DOI: $10.4000 /$ artelogie. 1420

ISSN: 2115-6395

Editor

Association ESCAL

Referencia electrónica

Andrea Giunta, «Arte, memoria y derechos humanos en Argentina », Artelogie [En línea], 6 | 2014,

Publicado el 24 junio 2014, consultado el 30 abril 2019. URL : http://journals.openedition.org/ artelogie/1420; DOI : 10.4000/artelogie.1420

Este documento fue generado automáticamente el 30 abril 2019.

Association ESCAL 


\title{
Arte, memoria y derechos humanos en Argentina
}

\author{
Andrea Giunta
}

1 El arte argentino contemporáno está fuertemente marcado por un impulso memorialista. La incesante producción de imágenes del arte y de iniciativas del Estado vinculadas a la memoria no están al margen de los síntomas de la contemporaneidad. Como señala Andreas Huyssen :

Uno de los fenómenos culturales y políticos más sorprendentes de los últimos años es el surgimiento de la memoria como una preocupación central de la cultura y de la política de las sociedades occidenteales, un giro hacia el pasado que contrasta de manera notable con la tendencia a privilegiar el futuro, tan característica de las primeras décadas de la modernidad del siglo XX (Huyssen $2007: 13$ )

2 Aunque esta frase fue escrita en los años noventa, el síntoma que Huyssen señalaba entonces se ha profundizado. Así como en los años ochenta comienza un tiempo de memorialización (Huyssen destaca que la serie televisiva Holocausto marca el comienzo de ese nuevo momento), en Argentina (y después en muchos otros países de América latina) se constituye C.O.N.A.D.E.P. ${ }^{1}$ cuyo informe se publica en 1984 con el título Nunca Más, un año año antes de comenzar el juicio a las juntas militares que fue realizado en 1985.

3 No se trata, por cierto, de un revival de la memoria vinculado a distintos pasados de la historia argentina, sino al pasado inmediato, el de la dictadura. Su persistencia en el arte más reciente señala, sin embargo, el desarrollo de un repertorio extenso que busca distintas formas de actualización de lo sucedido en ese tiempo. Una forma de volver presente ese pasado buscando evitar su clausura ; una investigación constante en torno a las texturas emocionales que las imágenes pueden provocar en su reflexión sobre lo sucedido en esos años y su persistencia en el presente. La acumulación de experiencias que configuran las formas del recuerdo, las estrategias para activar el contacto con distintos pasados, los diálogos entre imágenes, entre sus condiciones de producción y de reproducción y un complejo mecanismo de transformaciones de las formas de inscribirlas desde los textos: todo esto hoy constituye un corpus significativo, extenso y extremadamente complejo en el universo de las intervenciones visuales en la Argentina. 
4 Se trata de imágenes que migran entre tiempos y entre soportes, que saltan de la crónica y el álbum familiar a espacios que se vinculan al campo del arte y cuyo estatuto no es necesaria o estrictamente artístico. Son imágenes que no se desvinculan de las agendas políticas de los organismos de derechos humanos que reclaman justicia, pero que al mismo tiempo operan en ámbitos que suman el poder simbólico que les concede el espacio de las instituciones artísticas. ${ }^{2}$ Como si al llevar ciertas imágenes más allá del ámbito de la protesta callejera se les adhiriese un poder otro, en el que se funde la denuncia y el reclamo de justicia con las cualidades que la imagen posee para demorar la evanescencia de la acción. Son imágenes con un fuerte impulso archivístico y también memorialista. Registro y conmemoración respecto de un pasado cuyas pruebas se transforman continuamente con la aparición de nuevos registros.

5 Quizás haya que advertir que el impulso memorialista en el arte argentino no sólo se centra en el pasado ominoso más reciente. Una amplia producción de imágenes han indagado los estereotipos sobre los que se ha construido el imaginario de la nación. En el contexto de los bicentenarios se activó un imperativo reflexivo sobre iconografías emblemáticas del siglo XIX y del siglo XX que fijan distintos momentos en la constitución del estado nación. Las imágenes contemporáneas desconstruyen imágenes que se encuentran en el museo (escenas de conquistas, de raptos de cautivas, de epidemias emblemáticas, de héroes, de huelgas) interrogando la relación entre Estado y violencia ; entre nación y orden represivo ; entre nación, racismo y patriarcado.

6 Sin embargo, en este ensayo voy a detenerme en un conjunto de imágenes elaboradas en el campo del arte en relación con las violaciones de los derechos humanos durante la última dictadura argentina. Propongo visualizar el orden de un corpus complejo, que se articuló históricamente y que, en tal sentido, negoció formas de enunciación que fueron modificando sus dispositivos y sus agendas de acuerdo con los cambios que experimentaba el debate sobre los derechos humanos en la Argentina. Ligadas al campo del arte o del activismo político, estas series no responden al mismo regimen de producción ni tampoco circularon, cuando se formularon, por los mismos espacios. Fueron imágenes gestadas en distintos momentos históricos, situadas en diversos contextos políticos y jurídicos. Imágenes de resistencia y de denuncia que contaron, sobre todo a partir de 2004, con un marco de legalidad activado desde el Estado argentino. Y cada vez más con el de las instituciones de exhibición artística que las ingresa en el espacio de la sala, la reserva, la colección del museo desde las que funcionan como observatorio para el análisis cultural académico y curatorial.

7 Lo que quiero presentar en este texto es la aproximación a la cartografía histórica de un itinerario tensado entre el momento de un arte producido desde las sombras, en una situación casi clandestina, marcado por la censura y la autocensura, a otro en el que el Estado brinda edificios y recursos para desarrollar actividades culturales estrechamente ligadas a la memoria. El itinerario de estas representaciones se define en el recorrido que las lleva desde el aislamiento del taller al espacio estelar del museo ; desde la prohibición y el peligro de nombrar lo que sucedía en el país, hasta la apertura de exposiciones y de museos que vuelven imperativo el diálogo entre el pasado y el presente. El programa de un Estado comprometido con el recuerdo activo del pasado. Y también con la administración del recuerdo.

8 Abordar la forma en la que se fueron articulando históricamente estas estrategias de representación permite aproximarse a la relevancia del capital simbólico y político en juego ; nos deja ver hasta qué punto para la sociedad fue importante interceptar las 
estrategias del olvido, en qué medida las imágenes se tramaron desde escenarios múltiples, que se vincularon a los más públicos, de las imágenes impresas en los medios de comunicación o a las intervenciones en las manifestaciones, en las calles, hasta aquellas que se presentaron en museos y espacios de exhibición. Se trata, en definitiva, de considerar algunas de las estrategias simbólicas ligadas a las políticas de la memoria que desde las imágenes se formularon durante los últimos 30 años y que constituyen uno de los rasgos relevantes de la cultura contemporánea argentina.

\section{Imágenes presentes / ausentes en tiempo de violencia (1976-1983)}

La pulsión memorialista que desde comienzos del siglo XXI se manifiesta en América latina a partir de la sucesión de informes de distintas comisiones de la verdad y de una serie de monumentos, sitios y museos de la memoria recientemente inaugurados, no debe opacar la emergencia de imágenes que se formularon durante los años de la dictadura. En algunos casos imágenes opacas, alusivas, indirectas, poéticas. Imágenes que circularon en circuitos reducidos, en los espacios estandarizados del arte. Realizadas en un contexto social marcado por el terror, las listas, la censura, la autocensura, su sentido político radicó no tanto en su transparencia para referirse a la dictadura y denunciarla, sino en su capacidad de gestar comunidades en torno a significados que se creaban por identificación, a partir de la experiencia perceptual, intelectual y emocional que se compactaba en las imágenes y en su relación con los espectadores. Ellas decían de un modo distinto lo que en otros ámbitos no podía mencionarse. Aunque, en algunos casos, su mensaje era apenas un susurro, representaban una pequeña victoria sobre el terror y el objetivo máximo de la dictadura: erradicar definitivamente el pensamiento disidente. En tal sentido podemos pensarlas como prácticas simbólicas resistentes.

Sin embargo, sus formas de enunciación no pueden unificarse. Como señala George DidiHuberman, en "el discurso de lo inimaginable" (en este caso la muerte en la que estaba inmersa la sociedad Argentina durante los años de la dictadura, materializada diariamente en las calles y en los centros de detención) pueden "distinguirse dos regímenes diferentes y rigurosamente simétricos. Uno procede del esteticismo, que tiende a ignorar en la historia sus singularidades concretas. El otro procede de un historicismo, que tiende a ignorar las especificidades formales de la imagen." (Didi-Huberman, 2004 : 50). Dos casos sirven para desplegar estrategias diferenciadas en la relación entre dictadura y representaciones.

11 En 1976, todavía en Buenos Aires, en los meses previos a la partida con toda su familia hacia el exilio en Brasil, León Ferrari recortó de distintos medios periodísticos los artículos que describían la aparición de cuerpos atados, calcinados, fusilados en distintas ciudades de la Argentina y el hallazgo de cadáveres en las costas del Uruguay. 


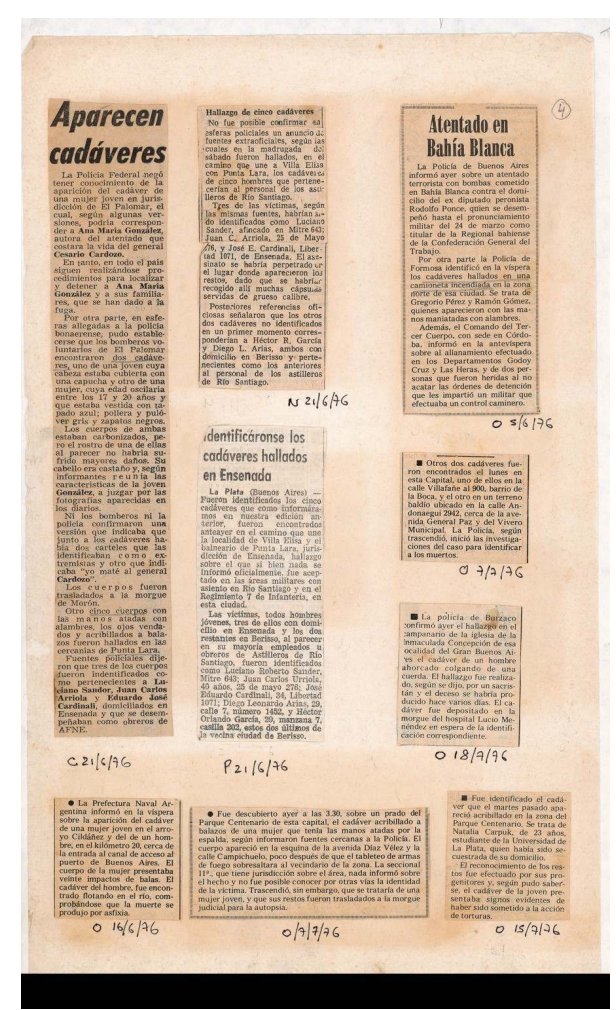

Collage de noticias periodísticas. 21,59 × $34 \mathrm{~cm}$.

Fundación Augusto y León Ferrari.

Pegó estos artículos en hojas de papel comunes, sin seguir parámetros estéticos, buscando cubrir toda la superficie del papel, rotando incluso el registro de la impresión, indicando sólo con una letra el medio periodístico en el que habían sido publicados y la fecha. Un archivo de urgencia, perseguido por la necesidad de reunir pruebas que no provenían del expediente secreto sino de las noticias que todos podían leer en la prensa de cada día. Ferrari envió estas hojas por correo a San Pablo, donde residiría hasta 1991. Allí fotocopió y distribuyó este archivo. ${ }^{3}$ Para Ferrari, el arte crítico, el arte político, tenía que denunciar con pruebas, volver incontestables los cuestionamientos e impugnaciones de la vida política y de la tradición de Occidente; proporcionar materiales para crear una nueva conciencia en el espectador. Ferrari había resuelto la tensión entre el arte y la política en su obra dividiéndola en dos alternativas. Por un lado los dibujos (a los que llamaba arte a secas o arte "lindo") y por el otro sus collages de imágenes y de objetos (a los que ubicaba dentro del arte político y de denuncia), entre los que se encuentran sus relecturas de la Biblia. ${ }^{4}$ Sin embargo, en un principio, el archivo de noticias obraba más como información, como prueba, que como acusación. En 1984 Ferrari imprimió un giro a este archivo convirtiéndolo en un expediente social. Volvió a publicarlo, también impreso en fotocopias, con el título "Nosotros no sabíamos", la frase que circuló entre un sector de la sociedad cuando se volvió incontestable que en la Argentina habían funcionado centros de detención clandestina, que habían desaparecido personas, que había niños nacidos en cautiverio. Confrontaba así a la sociedad - que utilizaba esta frase para justificar su inacción frente a las muertes y torturas de la dictadura-, con el archivo público, accesible a todos, en todos los medios, de lo que había sucedido en esos años. Se producía así un efecto entre el montaje del archivo y el título, única operación formal de una obra 
completamente impregnada de historicismo. ${ }^{5} \mathrm{El}$ papel amarillo, los dobleces, la marca del tiempo y los rastros de la urgencia, conceden a estos papeles un efecto de verdad inmediato. Desplegados en los muros de las instituciones del arte se ofrecen como imágenes que conservan la fuerza de una prueba, una toma de posición, un juicio social. El registro nos habla también de la naturalización de la violencia, de su normalización. Al mismo tiempo que difundía este archivo que obraba como prueba, León Ferrari viajaba a Italia, se ponía en contacto con Amnesty, trabajaba para contribuir a la intervención internacional en las violaciones de los derechos humanos en Argentina. ${ }^{6}$

13 No fue ésta, sin embargo, la única manera en que las imágenes vinculadas al campo del arte aludieron a la violencia. Otros registros se articularon desde operaciones que dialogaban más con la estética que con la historia. [] Y aun así, eran repertorios que recorrían los límites de lo decible y lo representable en un momento de extrema vigilancia, en el que podían verse ciertas cosas en esas obras, pero no podían expresarse en palabras públicas. No al menos sin riesgo para la propia vida. Grippo reúne objetos simples que no tenían ninguna capacidad de obrar como prueba de lo que sucedía, y que sin embargo refierían, desde la combustión de la imagen, a un universo colindante con el que describen los titulares de las noticias compiladas por Ferrari. La selección y la relación de estos objetos activan poderosas metáforas de la muerte.

Imagen 2. Victor Grippo. Valijita de panadero (Homenaje a Marcel Duchamp). 1977.

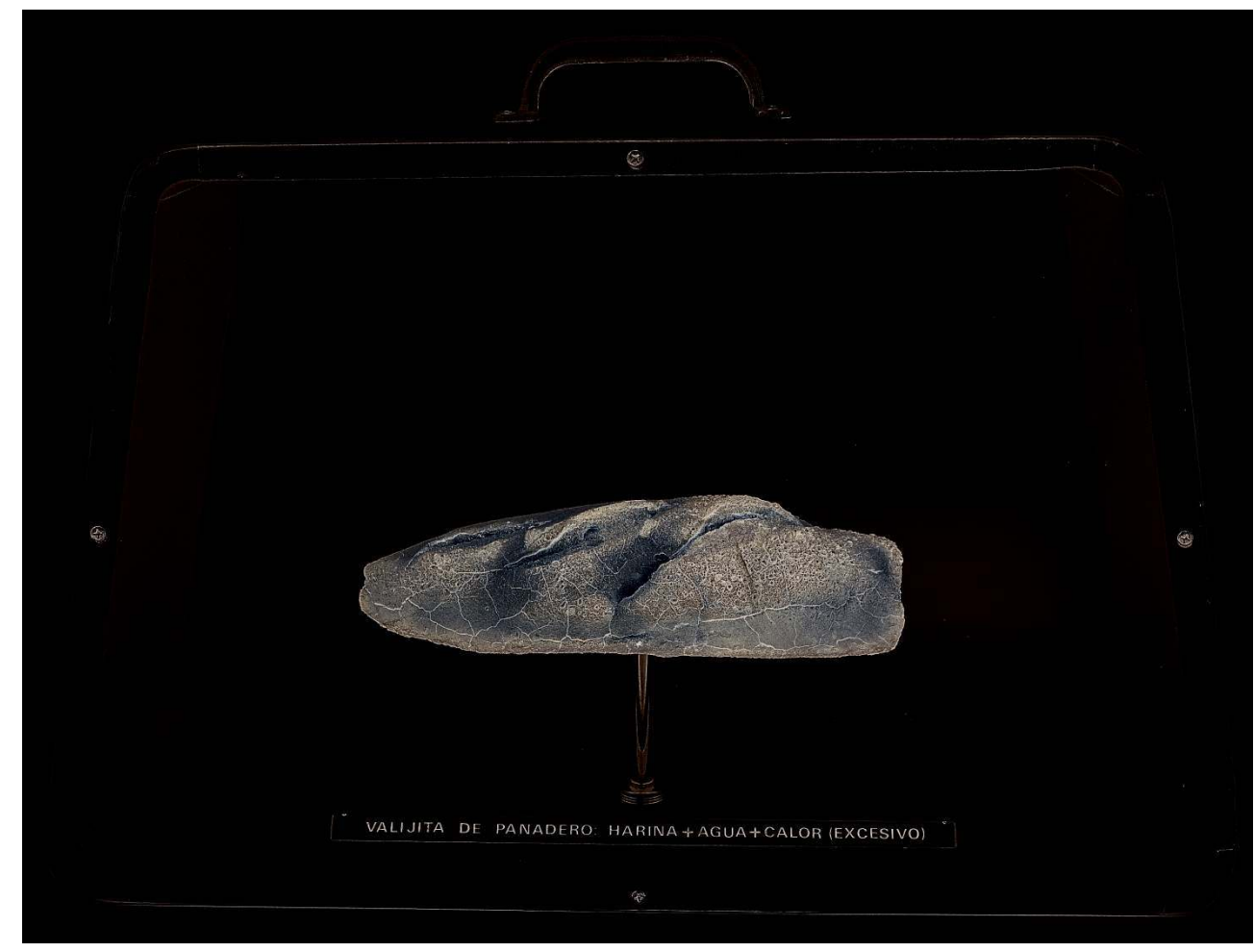

Pan quemado en caja de madera y vidrio. 32,5 × 51 × 20 cm, Colección particular

14 En Valijita de panadero (1977), Víctor Grippo coloca un pan carbonizado dentro de una maleta translúcida y le adhiere un texto "valijita de panadero: harina + agua + calor (excesivo)", en el que describe los materiales y enuncia el proceso de transformación de la materia por el fuego. A esta imagen se adhieren sentidos que provienen de la tradición iconográfica de Occidente y otros más circunstanciales, más inminentes, compartidos por 
quienes estaban inmersos en la sociedad del terror. Las formas eran aparentemente intrascendentes, pero se conectaban con un conjunto de acciones que tenían significados bastante precisos en ese lugar y en ese momento. El pan carbonizado, el pan que es en la tradición católica, cuerpo, se exhibe encerrado en una maletilla de vidrio. Las valijas, con sus fuertes referencias a la migración y el exilio, fueron significativas durante los años de la dictadura. No sólo remitían a las partidas forzadas, también a los enterramientos de publicaciones censuradas que se guardaban bajo tierra esperando a ser descubiertas y a volver a ser leídas cuando pasase el periodo de excepcionalidad. Pero el tiempo fue demasiado largo $\mathrm{y}$, cuando años más tarde se encontraron algunos de esos enterramientos, sus materiales estaban enmohecidos e ilegibles. ${ }^{8}$ La valija funcionaba también como el espacio de compactación de un universo de sentido, a la manera de la Boîte-en-valise de Marcel Duchamp. De hecho, la Valijita de panadero llevaba como segundo título, entre paréntesis, "homenaje a Marcel Duchamp" y era, en un sentido, un compendio de otra obra de Grippo. A fin de proponer una lectura del sentido de esta pieza en el contexto de su obra quiero introducir una anterior, realizada en 1972, en la exposición sobre Arte y política que se realiza en la Plaza Roberto Arlt poco después de los asesinatos en el penal de Trelew. ${ }^{9}$ Grippo construye, junto al escultor Gamarra y al artesano Rossi, un horno de barro para elaborar pan (Construcción de un horno popular para hacer pan, 1972). El pan fue realizado, cocido y distribuido entre quienes se encontraban en la plaza formando una comunidad transitoria. A través del uso de un mismo elemento, el pan, la valijita de panadero y el horno de pan permitían leer el tránsito entre la comunidad de solidaridades que se había producido en el espacio público y el aislamiento y calcinación de los cuerpos que se encontraban esparcidos por la ciudad. A diferencia de Ferrari, Grippo siempre resistió una interpretación lineal de su trabajo. Reconocía el impacto de la dictadura "La llegada de los militares -me decía en una conversaciónentrevista-forzó un cambio de lenguaje, la invención de nuevos códigos”. ${ }^{10}$ Sin embargo, él no ofrecía una descripción, testimonios ni pruebas.

Las obras de Grippo y de Ferrari representan dos formas de aproximarse a un tiempo señalado por la violencia. Ambos remiten a una señalización que apunta a volver evidente la relación entre presencia / ausencia de los cuerpos y de la información. Aquellos cuerpos que aparecían en la ciudad, de los que daba cuenta el períodico, pero de los que no se podía hablar, que no se podían representar. En el registro de una alusión opaca podría inscribirse también la serie de heliografías que Ferrari realiza desde fines de los años setenta en San Pablo. Arquitecturas en las que las personas, en esquemas estereotipados, repetidos, recorren los espacios enloquecidos o esperan, absolutamente a solas, rodeados de esas arquitecturas demenciales. Son series de gran tamaño que Ferrari enviaba, dobladas, por correo, vinculando el mail art con la obra mural. Arquitecturas que remiten a la noción de panóptico, como bien lo señaló Roberto Jacoby, y que develan la experiencia del espacio del centro de detención: "se trataba de una vasta cárcel. Una visión traspuesta de la teoría foucaultiana del poder. El dispositivo panóptico donde un ojo soberano vigila sin ser visto, mientras que los observados no se conectan entre sí más que parcialmente. Un territorio que se ordena con el fin de disciplinar." (Jacoby, 1987 : 164 y 169). Quienes las recibían tenían ante sí una inmensa trama de espacios imposibles, de espacios inhabitables; experimentaban, en otra clave, la relación con la opresión cotidiana. La confrontación de Nosotros no sabíamos con las heliografías produce inmediatamente la asociación entre la violencia real, ejercida por un Estado represivo, documentada con pruebas y la cotidiana, y aquella que se articulaba desde los dispositivos 
de control que disponían de la vida cotidiana. Eran, en su conjunto, ensayos de representación. Desde distintas redes simbólicas, en distintos espacios, se buscaban imágenes capaces de dar cuenta de lo que sucedía en las sociedades bajo sistemas de vigilancia represiva como los que se multiplicaban en los años setenta en distintos países de América latina. Se buscaba gestar registros de aquello que la dictadura querría borrar mediante auto indultos y destrucción de archivos. ${ }^{11}$

\section{Retratos de los desaparecidos y memoria de la dictadura}

16 También en la plaza pública se gestaban imágenes poderosas. La derrota de la guerra de Malvinas señala el momento en el que se vuelve incontestable la erosión del poder de la dictadura. Comienza un proceso difícil de reconquista del espacio público que se produjo sobre la base de movilizaciones reprimidas (como las del 30 de marzo y del 16 de diciembre de 1982) que se suman a la tarea que durante todos los años de la dictadura realizaron las Madres de Plaza de Mayo desde su primera marcha, el 30 de abril de 1977 y los distintos organismos de derechos humanos. Las marchas de la Resistencia realizadas desde 1981 suman los reclamos de "aparición con vida", "Juicio y castigo a los culpables" y "cárcel a los genocidas" que transitan la tensión entre la esperanza de encontrar a los desaparecidos y la certeza creciente acerca de su asesinato. Durante la $3^{a}$ marcha, el 21 de septiembre de 1983, poco antes de las elecciones del 30 de octubre que señalan el comienzo del proceso de la postdictadura, se realizó la acción visual, política y participativa conocida como El siluetazo (Longoni y Bruzzone, 2008) .

Imagen 3. Siluetas y Canas. Buenos Aires 21/22 de setiembre de 1983.

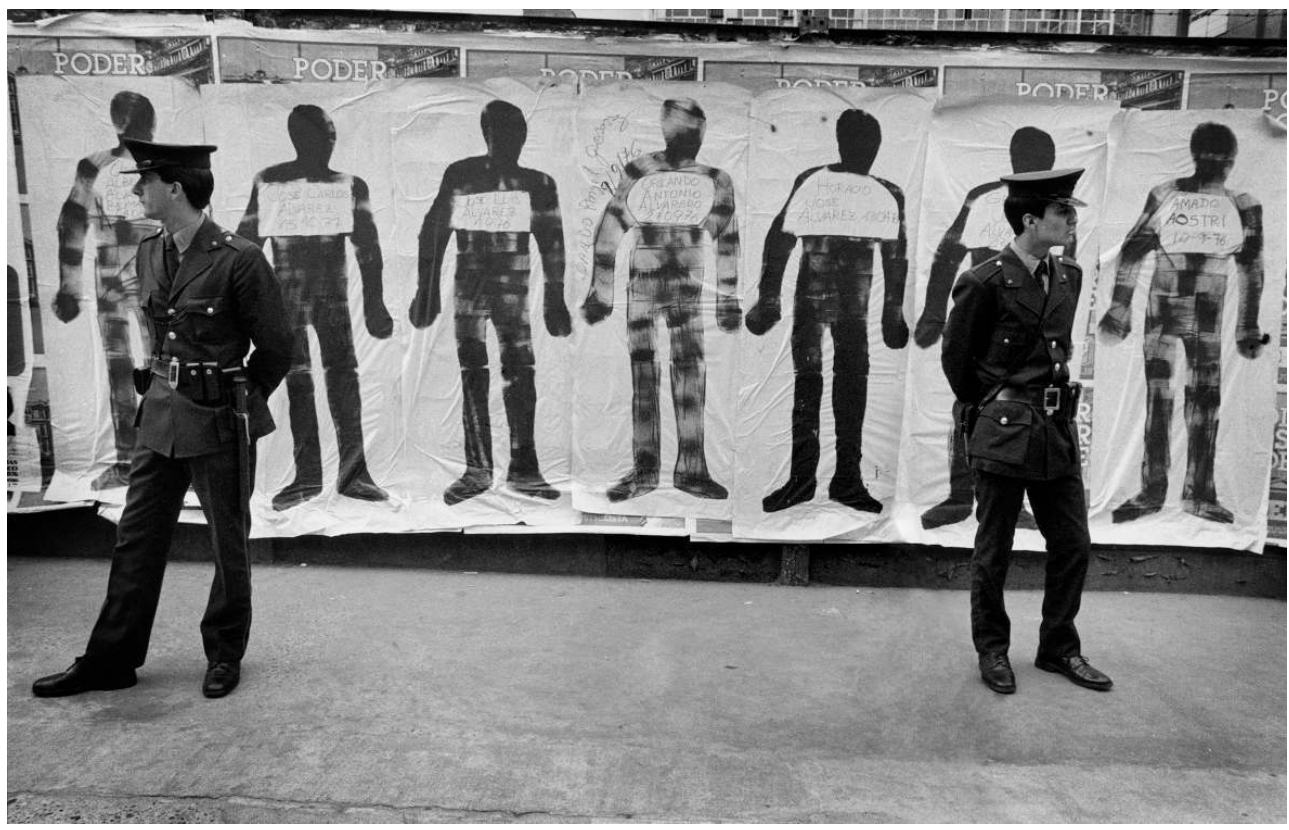

Fotografía de Eduardo Gil.

La visualización de las víctimas de un genocidio, la representación física, espacial, de lo que es tan sólo un número, es una de las tareas que las representaciones visuales tratan, con dificultad, de abordar. Parece imposible representar en términos espaciales las 
muertes de Auschwitz. Tal irrepresentatibilidad fue asumida por la síntesis que el artista polaco Jerzy Skapski elaboró para dar cuenta, visualmente, del genocidio perpetrado en este campo de concetración. 2.370 siluetas que representaban tan solo el número de personas que allí se asesinaban cada día. El esquema debía provocar el ejercicio mental de tratar de imaginar lo que, parece irrepresentable : el plan de eliminación de millones de personas en un tiempo reducido, llevado a cabo por el nazismo alemán, acelerado después de tener las primeras evidencias de que no ganarían la guerra una vez fracasado el avance sobre el frente oriental (Rafecas, 2012).

Durante la $3^{\mathrm{a}}$ marcha un grupo de artistas de distintas tendencias políticas, integrado por Rodolfo Aguerreberry, Julio Flores y Guillermo Kexel, buscaron dar una dimensión visual a la superficie que ocuparían 30.000 cuerpos, cifra en la que se sintetizó el número de desaparecidos. En el contexto de la marcha articulan un taller en el espacio de la Plaza de Mayo para elaborar en forma colectiva y participativa las siluetas que debían pegarse en las zonas aledañas. Una toma política y estética : como señaló Roberto Amigo "La toma estética, cuya parte principal es la pegatina de las siluetas, es fundamental para la definitiva apropiación de la Plaza. La toma política no se podría haber dado sin la toma estética, sobre todo porque la manera en que ésta se produce implica una recuperación de los lazos solidarios perdidos durante la dictadura" (Cerisola, 1993). Más que volver sobre las articulaciones de una acción que fue tempranamente descripta, interpretada y debatida en el campo del arte, ${ }^{12}$ me interesa detenerme sobre la historicidad que activa esta acción. Las imágenes del Siluetazo involucran un debate en torno a la figura del desaparecido y su representación. La distancia entre las propuestas iniciales de los artistas y las modificaciones introducidas por las Madres de Plaza de Mayo, es decir, la demanda que éstas hicieron de que las imágenes no se colocasen en el piso, sino en las paredes, buscando negar la relación de las siluetas con la muerte, ${ }^{13}$ dan cuenta de la problematicidad de la representación. Sobre esta dificultad volvieron, en forma insistente, durante los años subsiguientes las apropiaciones del retrato. Las siluetas no son retratos. Aunque en la marcha de la resistencia se inscribieron nombres y fechas de desaparición-quienes participaban de la manifestación lo hicieron-, los contornos inscriben la desaparición en la textura social antes que en la individual, más vinculada a la identificación. No son la huella, no se basan en la relación analógica con el cuerpo del desaparecido. Sus bordes corresponden, en general, a un cuerpo vivo, a un cuerpo presente que estuvo dispuesto a ponerse en el lugar de otro, ausente. Compartir la imagen del propio cuerpo para remitir a un cuerpo ausente era una forma eficaz de señalar que todos podríamos haber desaparecido o que todos éramos, en cierto modo, desaparecidos. Se interfiere así la idea de que el desaparecido es responsable de su propia muerte o desaparición que condensaban frases como "algo habrán hecho" o "por algo habrá sido", que circulaban junto al "nosotros no sabíamos". Las siluetas no representaban al desaparecido como víctima ni como militante; representaban la ausencia desde los cuerpos vivos que se habían prestado para establecer su contorno. Lo que vibra en esas imágenes es la fusión que despega al desaparecido del lazo exclusivo con su nombre o con sus familiares para entretejerlo con quienes brindaron su cuerpo para inscribir su representación social. En esta fusión se gesta un concepto de identidades desplazadas en el que la definición visual de un cuerpo proviene de otro cuerpo. Pero no es sólo la definición del otro, el desaparecido: el acto involucra la definición de uno mismo. También se define la identidad de quien yace para que dibujen el contorno de su cuerpo. El ciudadano, quien podemos sostener que coincide con la defensa de los derechos 
humanos, ya que se encuentra en la manifestación, se define desde el desaparecido, el otro que le afecta y le importa, diría Emmanuel Levinas (Levinas, 1993). No se trata de una relación cognoscitiva, se trata de una relación ética en la que el yo queda sustituido por el otro en una vínculo intercambiable entre el cuerpo presente del manifestante y el ausente del desaparecido.

El problema de la desaparición es político, jurídico y ético. Sus formas de representación se dirimen en la relación entre estos campos y desde los límites de la imagen. Ninguna resulta definitiva, ninguna es completa, las representaciones vuelven, insistentes, sobre sus pliegues, sobre sus zonas irresueltas.

Las figuraciones del rostro son recurrentes en el repertorio del arte más contemporáneo. No se trata de retratos en el sentido más tradicional, sino de imágenes inestables, en las que se desmarca el género del retrato para activar distintas formas o repertorios de representación del trauma social. Se trata de poner en crisis su visibilidad, su transparencia, la capacidad de ser simplemente un retrato. Esto se produce, especialmente, en el campo de la fotografía. Esta se desdibuja respecto de su especificidad para instalar una pregunta que muerde los bordes del postulado analógico y de los procedimientos técnicos de la fotografía. La repetición, la multiplicación incesante de las fotos vinculadas a los archivos públicos desde los que las instituciones del Estado administran las identidades, de las fotografías que provienen de los álbumes de familia, de los archivos de fotógrafos populares, desplazó, incluso, la producción de nuevas fotografías.

21 La demora del registro fotográfico se produce junto a un intenso movimiento de imágenes en el que las fotografías migran del retrato de identidad y el álbum familiar hacia otros registros que inauguran para ellas una nueva vida y las convierten en el punto de partida de una nueva experiencia (Giunta, 2010). ${ }^{14}$ ¿Cómo activar la imagen de quien no está pero que tampoco se puede probar que esté muerto? ¿Cómo representar ese intersticio, esa ausencia, ese estado de indeterminación? ¿Cómo hacer visible una vida suspendida?

En 2007 Gustavo Germano publicó un archivo para representar la ausencia desde el arrebato del tiempo vivido. Fotografió 15 veces la performance de fotos de álbumes de familia realizadas treinta años antes. 
Imagen 4. Gustavo Germano. Ausencias 1974

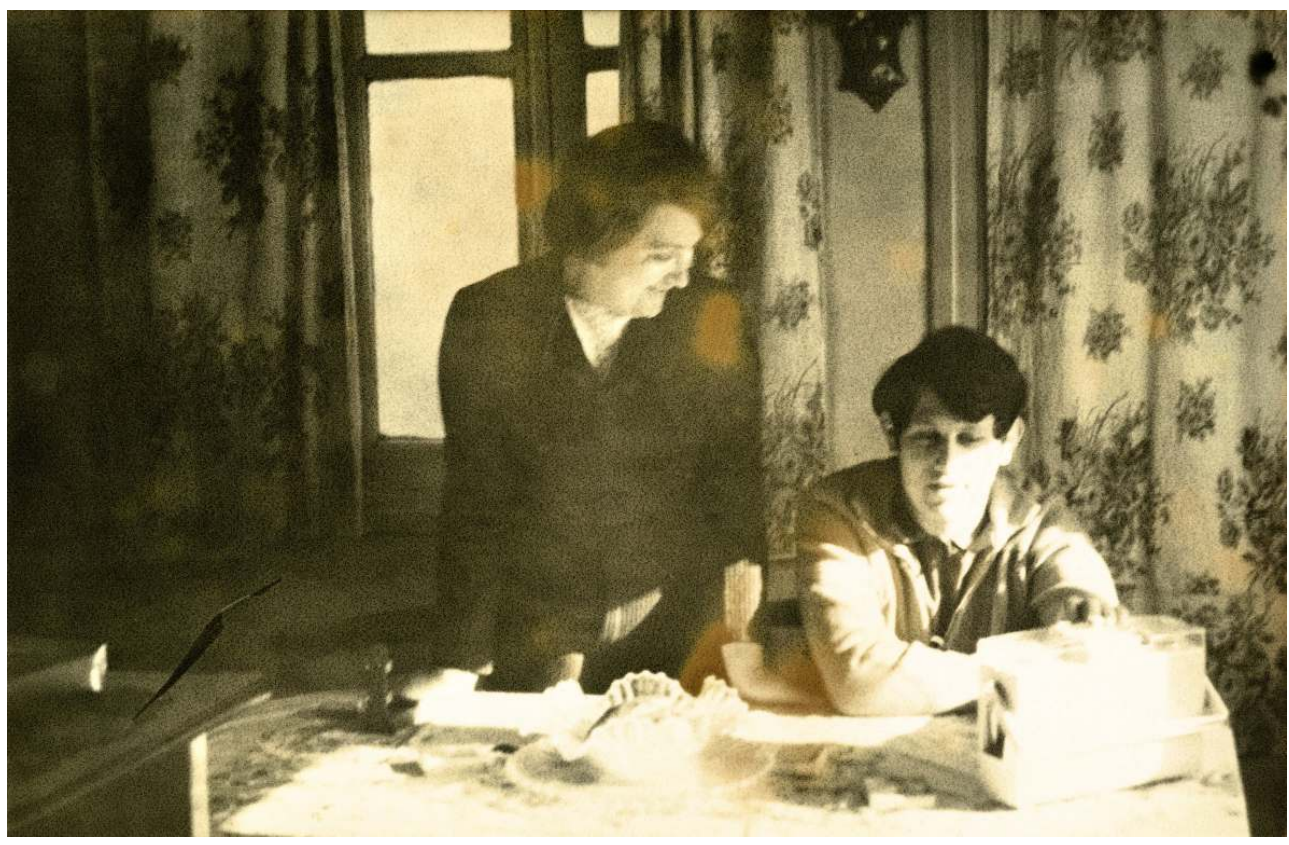

Imagen 4. Gustavo Germano. Ausencias 1974

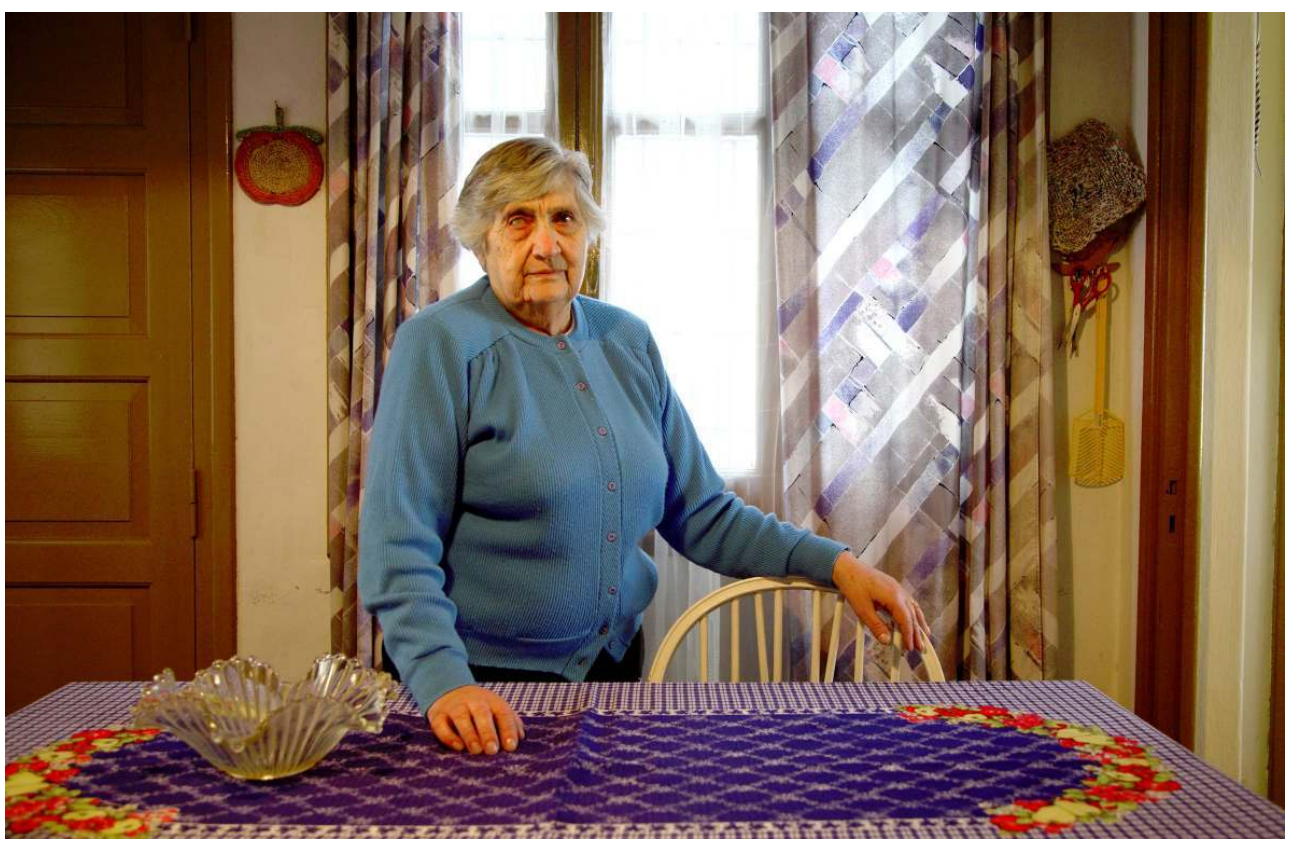

Clara Atelman de Fink Claudio Marcelo Fink

Al volver a fotografiarlas, dejó vacío el lugar de los cuerpos ausentes. Imaginemos el proceso de estas fotografías. La búsqueda y la selección de la imagen más elocuente, aquella capaz de mostrar mejor los vínculos con otras personas, una situación de intimidad y de afecto. Pensemos en la tarea de coordinación de tiempos entre quienes tenían que volver a posar, en la búsqueda del espacio en el que se sacó la primera foto, en las dificultades para encontrarlo. Tuvieron que conversar para compartir los recuerdos sobre el momento en el que se hizo la fotografía, sobre el lugar, acerca de cómo fue ese 
día, de dónde venía la luz en el momento de la fotografía. Tuvieron que reconstruir las referencias, los marcos de las puertas, los muebles, ensayar las posiciones, pensar si era posible adoptar el mismo gesto, borrar las sonrisas, girar el rostro y mirar al fotógrafo ; en ese giro, encontrar la mirada de otros, extraños a la intimidad del album familiar. Un desnudamiento de la intimidad. ${ }^{15} \mathrm{La}$ eficacia de estas imágenes radica en que no precisan ningún texto. Ellas expresan la particular inscripción que Germano quiere darles como registro no sólo de la desaparición de los cuerpos, sino también de la experiencia del tiempo. Un tiempo que se registra en las transformaciones de los rostros, de los cuerpos; que puede verse en las remodelaciones de la arquitectura, en los cambios en el paisaje. Germano expuso las fotografias en el Centro Cultural Recoleta (2008) en un tamaño equivalente al de las figuras reales. Introdujo así otra dimensión de la desaparición, representó la textura de las experiencias, los contactos cotidianos y la intimidad definitivamente arrebatados.

Muchos familiares no cuentan con estas fotografías. Forman parte de las generaciones posteriores, que conocen sobre lo que sucedió en su familia por relatos, testimonios y retratos. En 1999 Lucila Quieto, militante en ese momento de H.I.J.O.S., ${ }^{16}$ elabora una forma de estar presente en las pocas fotografías que tenía de su padre, en aquellas imágenes que hasta entonces había mirado desde afuera.

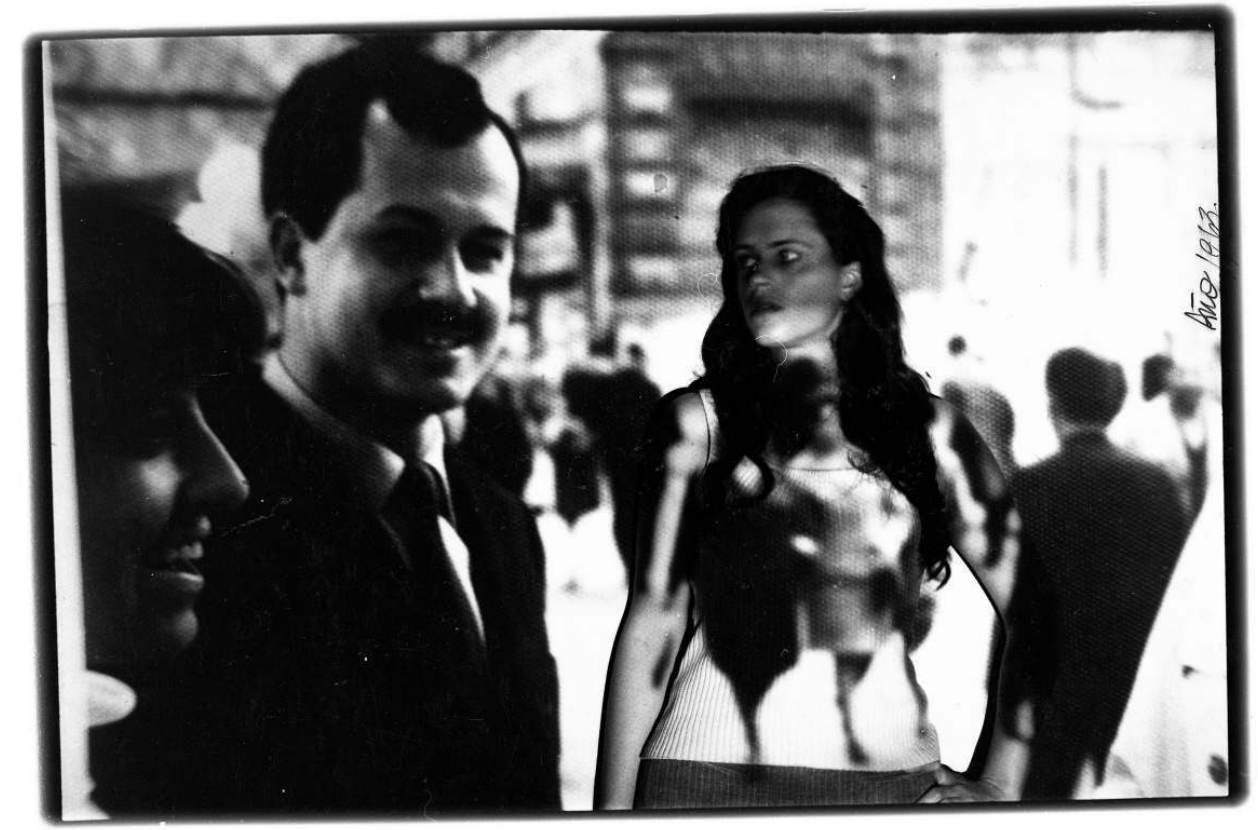

Ella deseaba lograr una fotografía imposible con su padre, desaparecido cinco meses antes de que ella naciera. Una imagen reparadora, que resistiese, desde un instante fantasmático, la fuerza aniquiladora de la dictadura. "Para mí fue un trabajo reparador a través de la imagen : la imagen que nunca había podido tener”, dice Lucila Quieto (Quieto, 2013). Pero lo personal encontró un registro social cuando otros hijos le pidieron que los fotografiara con sus padres. Estas fotografías pueden inscribirse en las prácticas de la memoria que Marianne Hirsch denominó “postmemory” (Hirsch, 1997). El término describe la relación de las generaciones posteriores con aquellas directamente 
involucradas en la represión. Se refiere a la forma en la que experimentan el trauma personal y colectivo a través de historias, imágenes y comportamientos entre los que, en muchos casos, crecieron. Lucila Quieto elaboró la experiencia de esa fotografía a partir de procedimientos de montaje y de yuxtaposición que le permitieron lograr esa imagen de la ausencia, el padre que no conoció, con cuya existencia estuvo en contacto por medio de fotografías y relatos. El poder de las imágenes es, en este caso, el de dar soporte a un deseo ; proporcionarles un grado de realidad. Su eficacia puede medirse en los pedidos de hijos y familiares de desaparecidos que la llevaron a fotografiar la reconstrucción de los vínculos familiares de otros. ${ }^{17}$

\section{Museografías de la memoria}

Las formas de interrogar el pasado para impedir su borramiento se expresan tanto en las imágenes de los artistas como en las iniciativas del Estado, impulsor de una fuerte política de la memoria que se expresa, sobre todo, en la organización de espacios de la memoria. ¿Cómo convertir el espacio de un museo en un lugar para la memoria, para el recuerdo, para el desarrollo de una tarea educativa $\mathrm{y}$, como siempre sucede con los museos, formativa de ciudadanía?

Desde fines de los años noventa los sitios, memoriales y museos de la memoria se han multiplicado en el mundo. En términos generales, estos proponen articular en el espacio la experiencia del pasado desde distintas estrategias cognitivas que involucran tanto el documento como la emoción. Se trata de proveer material para acceder a los hechos del pasado. Las fotografías, mapas familiares, cartas, objetos, cronologías, material periodístico, grabaciones y filmanciones se introducen como pruebas y como testimonios. Por ejemplo, en las salas de exhibición que se despliegan debajo del Memorial a los judíos asesinados de Europa de Peter Eisenman o a través de las fotografías y documentación que se incluyen en el Museo de la Memoria y la tolerancia de la ciudad de México. El acopio de objetos está sujeto a distintas condiciones. En primer lugar aquellas que provienen de los límites que la ética señala acerca de la exhibición de la violencia. ¿Qué es lo que se puede mostrar, hasta qué punto se puede representar el horror sin caer en su simple ilustración, o, incluso, sin contribuir a su reproducción por medio de la fascinación? En segundo lugar lo que se expone está condicionado por el grado de acuerdo respecto de las versiones del pasado que el museo quiere acercar a la experiencia presente del público: ¿cuándo comienza y cuándo termina el período que el museo relata?, ¿quiénes son sus protagonistas, quienes los responsables, quiénes las víctimas?

El museo no busca solo informar, también quiere conmover, provocar un estado de reflexión que transforme la conciencia. En tal sentido puede identificarse un paradigma formal del arte de la memoria. Memoria, en este caso, entendida no tanto como la capacidad de traer al presente un aspecto particular de la historia, sino como el programa de transformación de la conciencia del individuo, ese espectador particular al que la contemplación conmueve transformando en otro : un ciudadano capaz de oponerse a toda violación de los derechos humanos. La pérdida, señala Judith Butler, tiene un efecto transformativo (Butler, 2011). Pero ese efecto no se define de una vez, se experimenta a la manera de olas sucesivas que van aproximándonos a las dimensiones de lo que hemos perdido. 

mutar al individuo, de sensibilizarlo. Existe un larga tradición en el uso meditativo del arte. Las iconografías, pero sobre todo los lenguajes, la forma en la que se ordena el espacio, el uso de determinados colores o de la luz misma, como fuerza capaz de activar el espacio, constituyen una tradición extensa en la relación entre formas y religión (Laeuchli, 1980). Sus dispositivos se organizan desde un lenguaje que recurrentemente utiliza la abstracción, la luz y la insistente presencia de las diagonales. Un lenguaje formal que acompaña el recuerdo, la mirada hacia el pasado, para provocar en el público un tiempo de reflexión transformadora. Encontramos estos repertorios, repetidos, en los museos de la memoria, organizando tanto su arquitectura como el relato de su museografía.

Introduzco aquí un análisis del Memorial a los judíos asesinados de Europa, en Berlín, como ejemplo paradigmático de las formas meditativas que se encuentran también en los museos de América Latina y en Argentina. Las formas, imágenes y experiencias se articulan en dos espacios. Abajo las fotos, los testimonios, los mapas, los micro relatos que amplían el archivo de una víctima, de una familia. Las pruebas del genocidio. Arriba los bloques pétreos de condición monumental. Cubren $19.000 \mathrm{~m} 2$, son 2711 estelas que juntas suman 8 toneladas de materia. Pero más poderosa que la descripción es la experiencia. El recorrido de ese espacio implica caminar entre bloques cuyo tamaño cambia al mismo tiempo que se modifican los niveles del suelo. Toda la organización del espacio busca producir una leve inestabilidad, desacomodamiento, sobrecogimiento. No hay una sola imagen que nos remita a los campos de concentración, no se escriben nombres, no se registran fechas. Todo radica en sentir en el cuerpo las alturas, los desniveles, la imposibilidad de ordenar definitivamente un espacio que siempre se nos presenta como sorpresa. Aun sin movernos, sentimos su fluctuación. Los desniveles, cortes, cambios de altura, se acentúan cuando nos desplazamos entre los bloques, cuando vemos a los otros aparecer y desvanecerse entre la forma nítida de cada contorno de las formas pétreas. Experiencias físicas y perceptuales. Son formas meditativas que suspenden la facticidad de la historia para procesarla como emoción. Estar allí, permanecer en ese espacio ; las formas producen, ellas mismas, una experiencia para recordar. No relatan los hechos, mantienen en movimiento la conciencia a partir de una arquitectura capaz de producir una marca perceptual, un recuerdo procesado desde el propio cuerpo. ${ }^{18}$

31 El parque de la Memoria de Buenos Aires también implementa formas de recorrido que involucran un proceso transformativo. ${ }^{19} \mathrm{El}$ Monumento a las Víctimas del Terrorismo de Estado requiere, en principio, una lectura archivística. 
Imagen 6. Parque de la Memoria. Monumento a las víctimas del terrorismo de Estado. Buenos Aires, 16 de abril de 2014.

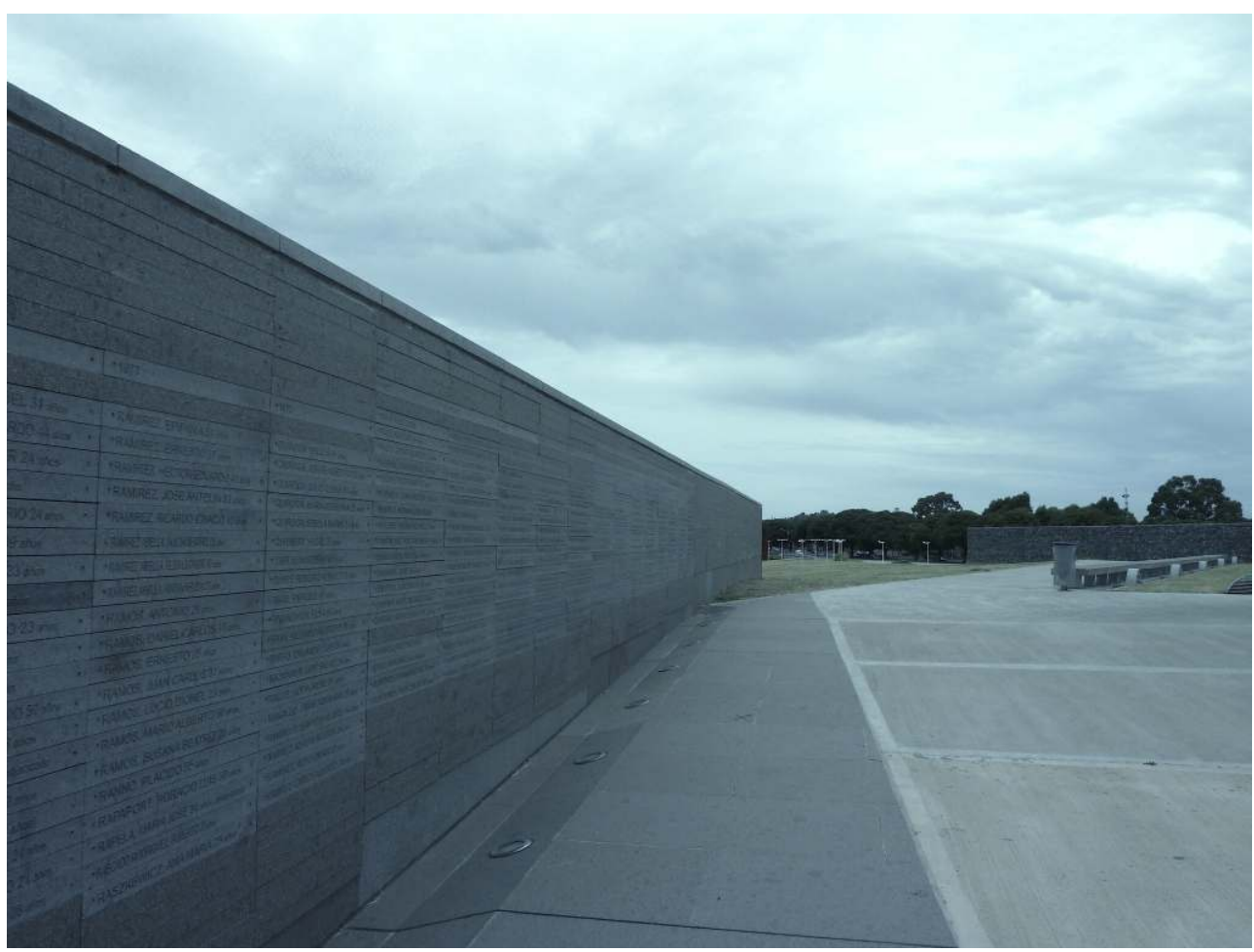

Foto : Andrea Giunta

El monumento reúne nombres de las víctimas del terrorismo de Estado entre 1969 (fecha del Cordobazo) y 1983. La decisión de ampliar el corpus de nombres a los años anteriores de la última dictadura, años de otras dictaduras (y también de un periodo de democracia, el marcado por el gobierno de Cámpora, de Juan Domingo Perón y de Estela Martínez de Perón, entre 1973 y 1976), fechas consensuadas por diversos organismos de Derechos Humanos, apunta a señalar la continuidad de la violencia de Estado, la gestación de un plan que fue anterior a 1976 y que implementó procedimientos semejantes, aunque no en la misma escala, ni con igual grado de sistematización. Buscamos, entre los nombres, ordenados cronológica y alfabéticamente, aquellos que conocemos. Tenemos que pensar cuándo sucedió; los años vividos se compactan, no tienen la transparencia de la cronología. Cuando reconocemos amigos, familiares, amigos de nuestros amigos, el monumento se convierte en lápida, en cenotafio. Ponemos el nombre en correlato con una vida. Por eso se dejan pequeñas flores en las ranuras entre nombre y nombre, en el espacio microscópico entre las placas de piedra. 
Imagen 6 -1. Parque de la Memoria. Monumento a las víctimas del terrorismo de Estado, detalle. Buenos Aires, 19 de marzo de 2010.

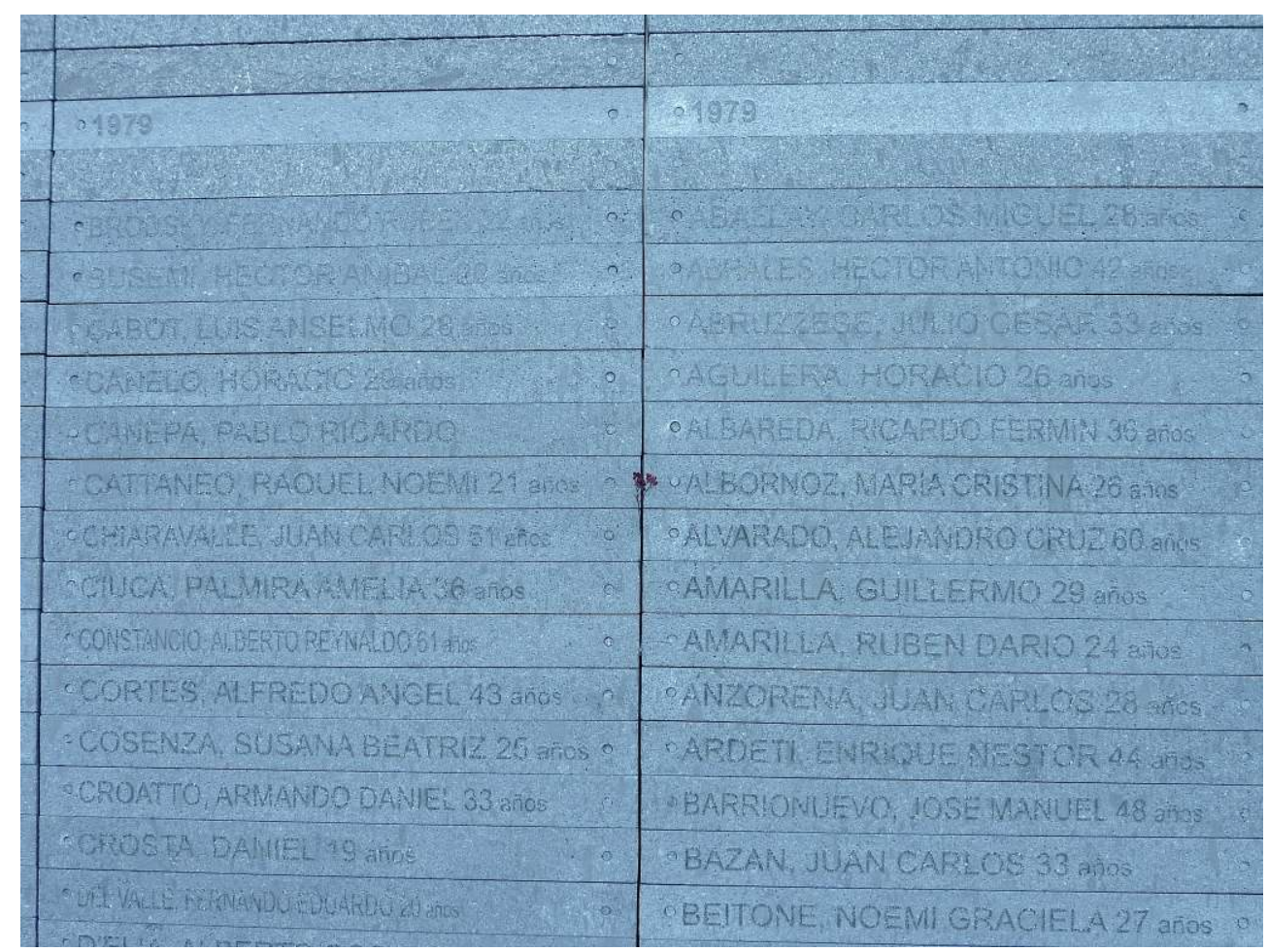

Foto : Andrea Giunta

Un nombre, una persona, alguien que conocimos. Al mismo tiempo el monumento, en su recorrido, responde a una forma meditativa. Funciona como un artefacto que produce, desde su forma específica, emociones. Entre el ingreso al parque y el río se despliega el recorrido articulado en un zig zag. Caminamos por un paisaje plano, con puntos de vista recortados entre el cielo y el río, sin interferencias de la ciudad. Recordemos que se trata del río-cementerio, aquel al que fueron arrojados los cuerpos vivos, topoi de una iconografía con base histórica, contextual, local. La forma en la que se organiza el espacio, con puntos de fuga y rotaciones que nos colocan ante nuevos planos diagonales cubiertos de nombres, desordena el punto de vista único. Nos obliga a mover nuestro punto de vista, a caminar en direcciones distintas. ${ }^{20}$ Este desacomodamiento que se produce en el recorrido colabora en la construcción de una alegoría sobre la experiencia y la complejidad del pasado, una alternativa ante el relato lineal de la historia. ${ }^{21}$ Los dispositivos meditativos involucran la experiencia de quedarse con uno mismo, navegando pensamientos y emociones, generan una percepción nueva cuyo estado afectivo vamos a recordar. Hacen de ese pasado, que podemos no haber vivido directamente, una experiencia presente.

El desarrollo de este paradigma de formas meditativas se constata en los museos y de la memoria y en los memoriales desde los que se ha conformado una institucionalidad emocional que busca formar una sensibilidad social hacia los derechos humanos.

En las museografías de la memoria se ha buscado introducir el doble régimen, estético e histórico, de lo "inimaginable". El histórico se centraliza en los archivos, que ordenan y se abren al público a partir de un acceso on line en la sala de exposición o mediante las bibliotecas (este es el acceso que brinda el Parque de la Memoria). También radica, en 
muchos casos, en la historia del edificio : un lugar en el que funcionó un centro de detención y tortura, ocupado generalmente por unidades de las Fuerzas Armadas. El edificio es prueba, testimonio ; allí se puede entrar en contacto con el lugar en el que lo inimaginable sucedió.

En tanto el Parque de la Memoria fue construído sobre un terreno ganado al río en un espacio vacío que actúa como uno de los recursos sobre los que se articula el carácter meditativo del espacio, otros lugares destinados a la memoria se instalan en edificios impregnados de pasado, que funcionan, en sí mismos, como testimonios, como prueblas. No se trata sólo de retórica arquitectónica, de dispositivos de administración de las formas que permiten una perticular percepción emocional, sino del impacto de saber que allí, en el mismo lugar que estamos recorriendo, sucedieron los hechos que se recuerdan.

Entre 1976 y 1983, en las numerosas manzanas de la Escuela de Mecánica de la Armada y su campo de deportes funcionó el centro de detención, tortura y asesinatos más emblemático de la Argentina. El 24 de marzo de 2004 el gobierno anunció la creación del Espacio Memoria y DDHH (ex-ESMA) y en 2007 se estableció el Ente Público Interjurisdiccional Espacio para la Memoria y para la Promoción y Defensa de los Derechos Humanos que tiene a su cargo la administración del predio. En su conjunto, el Espacio tiene como propósito la promoción de valores democráticos y la defensa de los derechos humanos. Las actividades se desarrollan por medio de visitas guiadas, congresos, ciclos de cine, programas educativos, exposiciones. Es un complejo integrado por un archivo, un canal de televisión, centros culturales y asociaciones, ${ }^{22}$ que involucra a los organismos de derechos humanos. ${ }^{23}$

En el predio se encuentra el edificio del Casino de Oficiales, donde desarrollaban sus actividades las máximas jerarquías. Por aquí pasaron más de 5000 detenidos, muchos hoy desaparecidos. Declarado Monumento Histórico nacional en 2008, es también prueba material en la investigación de la justicia. Por esa razón no ha sido remodelado ni intervenido por exposiciones o por una señalización invasiva. Para conocer el espacio hay que inscribirse para una visita que implica un recorrido acompañado del relato de una de las guías. Apenas hay algunos carteles colocados en atriles que incluyen datos o frases de testimonios. ${ }^{24}$ La percepción general es la de un espacio absolutamente vacío por el que un grupo camina, durante tres horas, siguiendo a la guía y descubriendo a partir de datos mínimos, casi invisibles, las marcas de lo que allí sucedió. La voz nos describe dónde estaban las celdas, nos lleva a imaginarnos las condiciones en las que estaban los presos, dónde y cómo transcurrían sus días, hasta qué punto desde donde ellos estaban pudieron escuchar los gritos de la ciudadanía festejando los goles del mundial de 1978, sobre todo cuando los partidos se jugaban en el cercano estadio del club River Plate. Se camina el edificio y se vuelven significativas marcas y datos que adquirieron sentido a partir del testimonio de quienes allí estuvieron en cautiverio. Los prisioneros recuerdan que cuando ingresaban, vendados, con una bolsa en la cabeza, sentían que las ruedas del auto saltaban dos veces, dos pequeños golpes. Varios relatos describían esto. Todavía puede verse en el asfalto la marca que dejó la cuerda que se bajaba al nivel del piso cuando ingresaban los autos. 
Imagen 7. Espacio para la memoria (ex Escuela de Mecánica de la Armada), Casino de Oficiales. Buenos Aires, 10 de agosto de 2012.

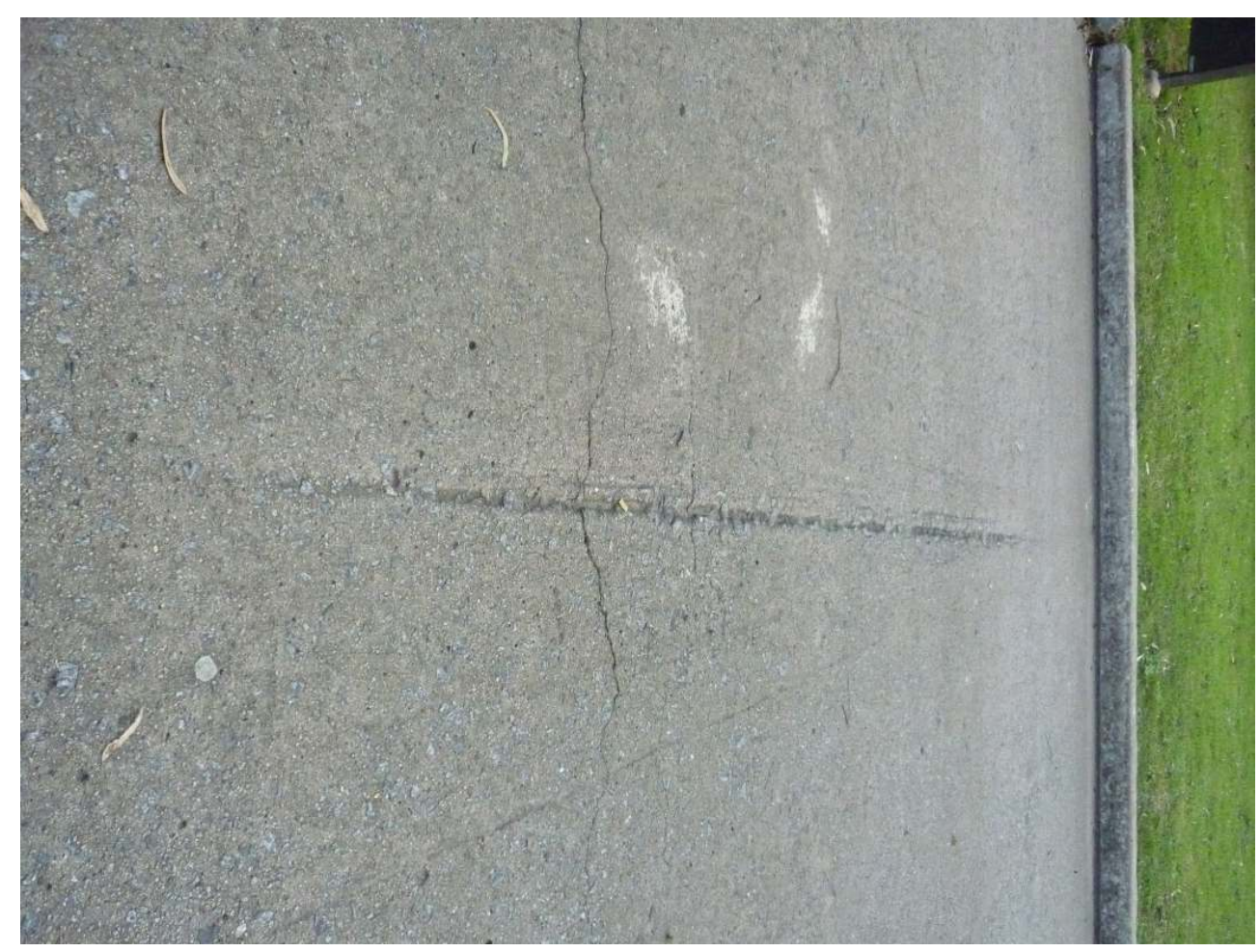

Foto : Andrea Giunta

Cada huella, cada detalle mínimo, remite a alguno de los momentos que conformaban los pasos de la maquinaria minuciosa que articuló la dictadura en su plan sistemático de eliminación de personas. La percepción de estos detalles nos conduce repetidamente a la experiencia del terror. Aquí no se trata de fotografías que registran un episodio, no se trata de mapas que señalan donde estaban los centros de detención en la ciudad, se trata del momento en el que la voz vuelve significativas las huellas que hasta ese momento permanecían imperceptibles. La emoción no proviene de la retórica del espacio ni del diseño que nos propone un artista, sino de la tarea de volver visibles los rastros casi imperceptibles de lo que allí sucedió.

En la Ciudad de Rosario se funda, en 1998, a partir de una ordenanza del Consejo Municipal, el Museo de la Memoria, instalado, en el año 2010, en un edificio que había estado ocupado por el Comando del II Cuerpo de Ejército, sede en la que se diseñó y desde la que se administró el plan represivo que se articuló en seis provincias argentinas. Allí acudían quienes buscaban a sus familiares desaparecidos durante la dictadura.

El Museo se centra en una aproximación al pasado desde el arte contemporáneo. Para el diseño de su museografía se convocó a artistas de la ciudad para que produjesen una obra sobre ejes temáticos propuestos desde la institución. En cada una de las aproximaciones, las obras "desandan la historia de la violencia de Estado en América, rearman testimonios de la lucha por los derechos humanos, reconstruyen el mapa de los centros de detención y tortura en el país, redibujan la gesta de las Madres y Abuelas de Plaza de Mayo" ${ }^{25}$ Las propuestas que reinterpretan la historia se ordenadan en una serie de núcleos temáticos : Memoria, Nos Queda la Palabra, Lectores, Reconstrucciones, Ronda-La Ardiente Paciencia, Evidencias, Pilares de la Memoria, Justicia perseguirás, A las víctimas de la espera y Entre 
nosotros. Dos piezas adquieren carácter emblemático por su carácter emocional y porque logran condensar la idea de monumento. En el primer sentido se destaca la pieza de Graciela Sacco, construida en un sector circular del museo, señalado por una sucesión de tramos entre los que la artista coloca espejos y placas transparentes impresas con ojos ( Entre nosotros).

Imagen 8. Graciela Sacco. Entre nosotros, 2010

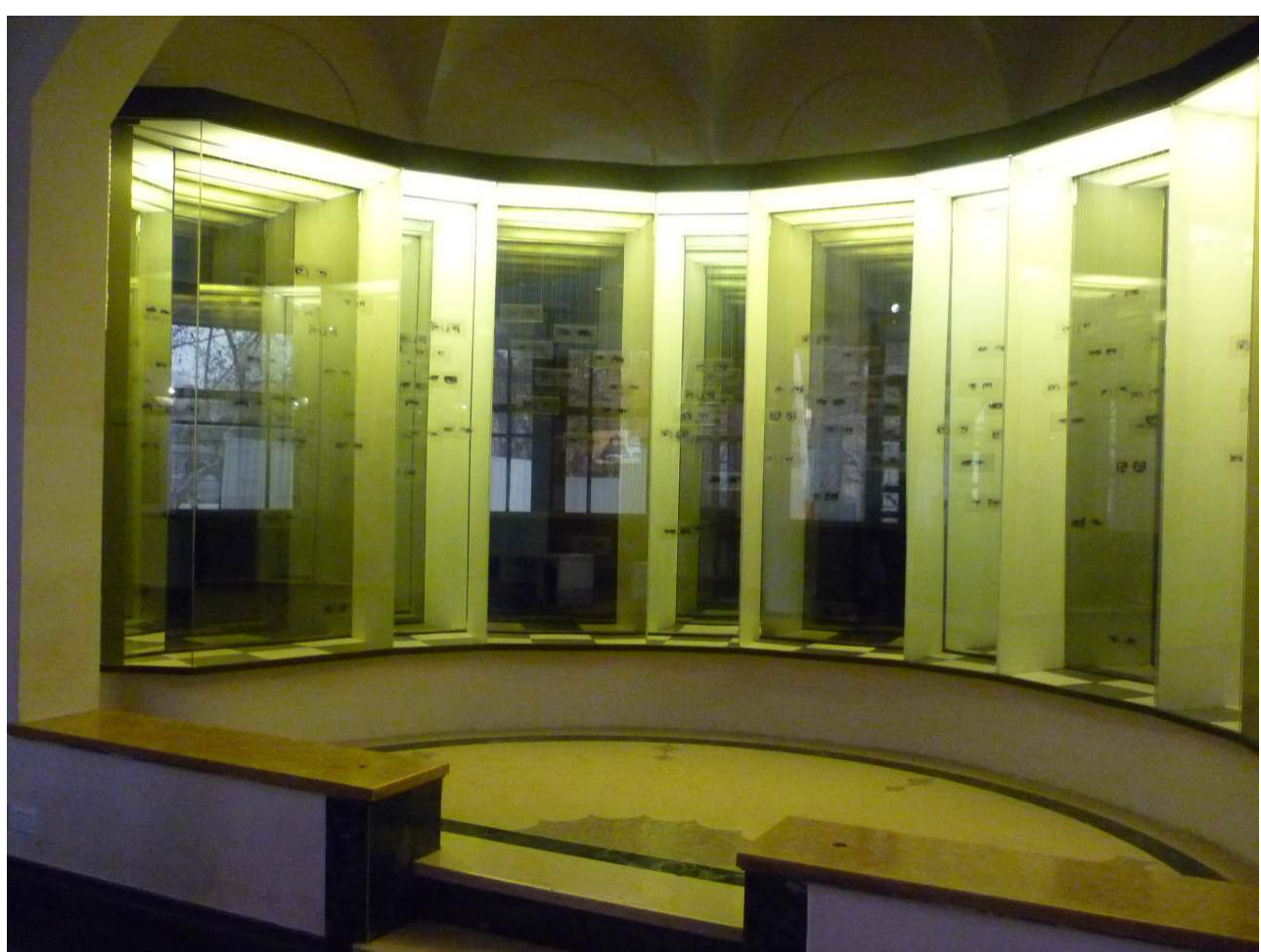

Museo de la Memoria.

Rosario. Foto : Andrea Giunta 
Imagen 8.1. Graciela Sacco. Entre nosotros (detalle). 2010.

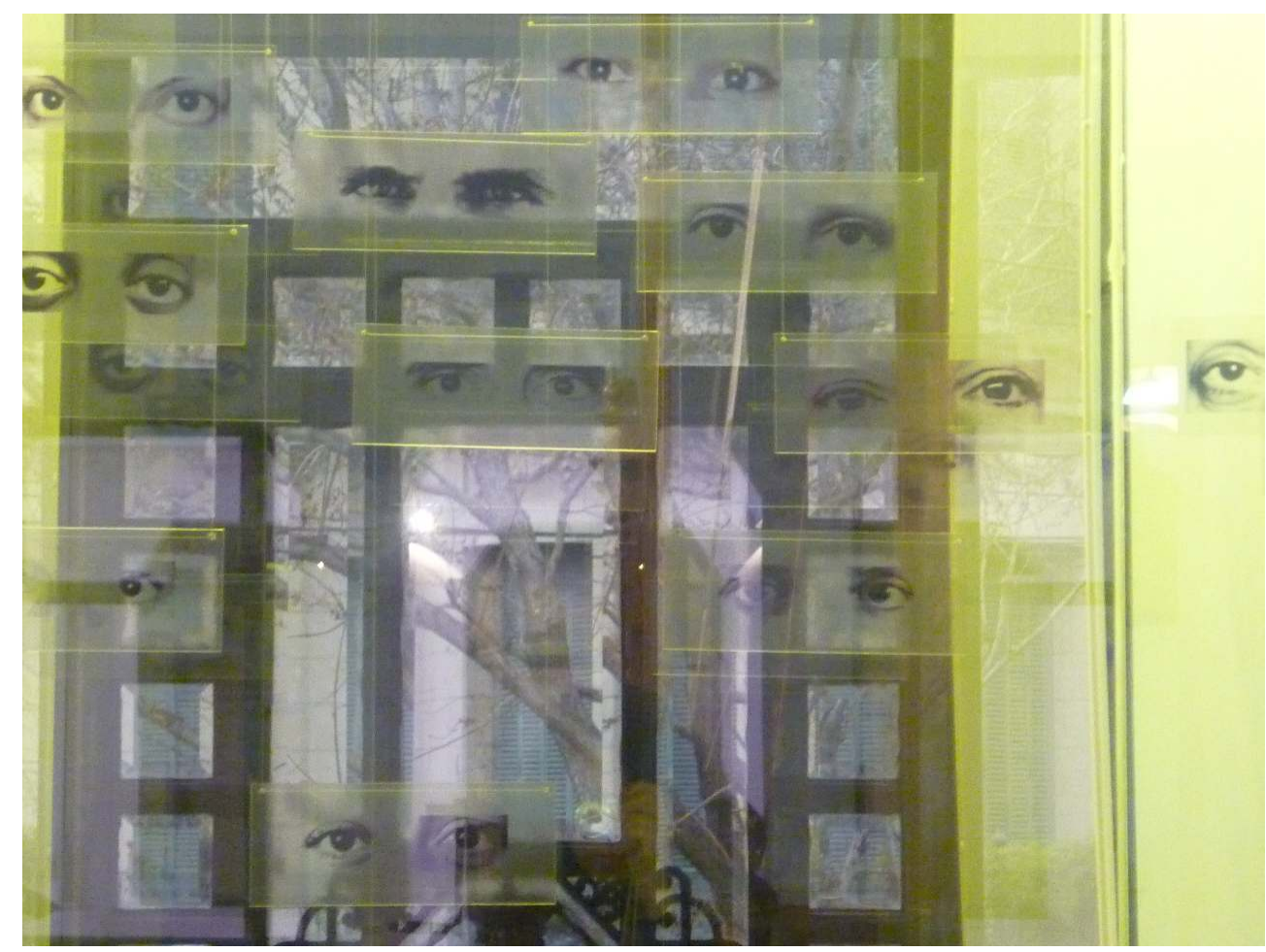

Museo de la Memoria. Rosario

Foto : Andrea Giunta

La pieza remite a la instalación urbana que desplegó en las calles, muros y escalinatas de Venecia en el año 2001 durante al 49 bienal realizada en esta ciudad. En aquella ocasión imprimió miles de ojos que desperdigó por Venecia logrando convertirla en una ciudad que miraba a todos los que la recorrían. Entre nosotros, el título de la obra, remite a todos aquellos que participaron de la represión y que aún estan libres, y también a aquellos secuestrados y desaparecidos, que siguen entre nosotros en forma de recuerdos, memorias, afectos. La segunda pieza, aquella que condensa la idea de monumento, es la de Martín Gatto. 


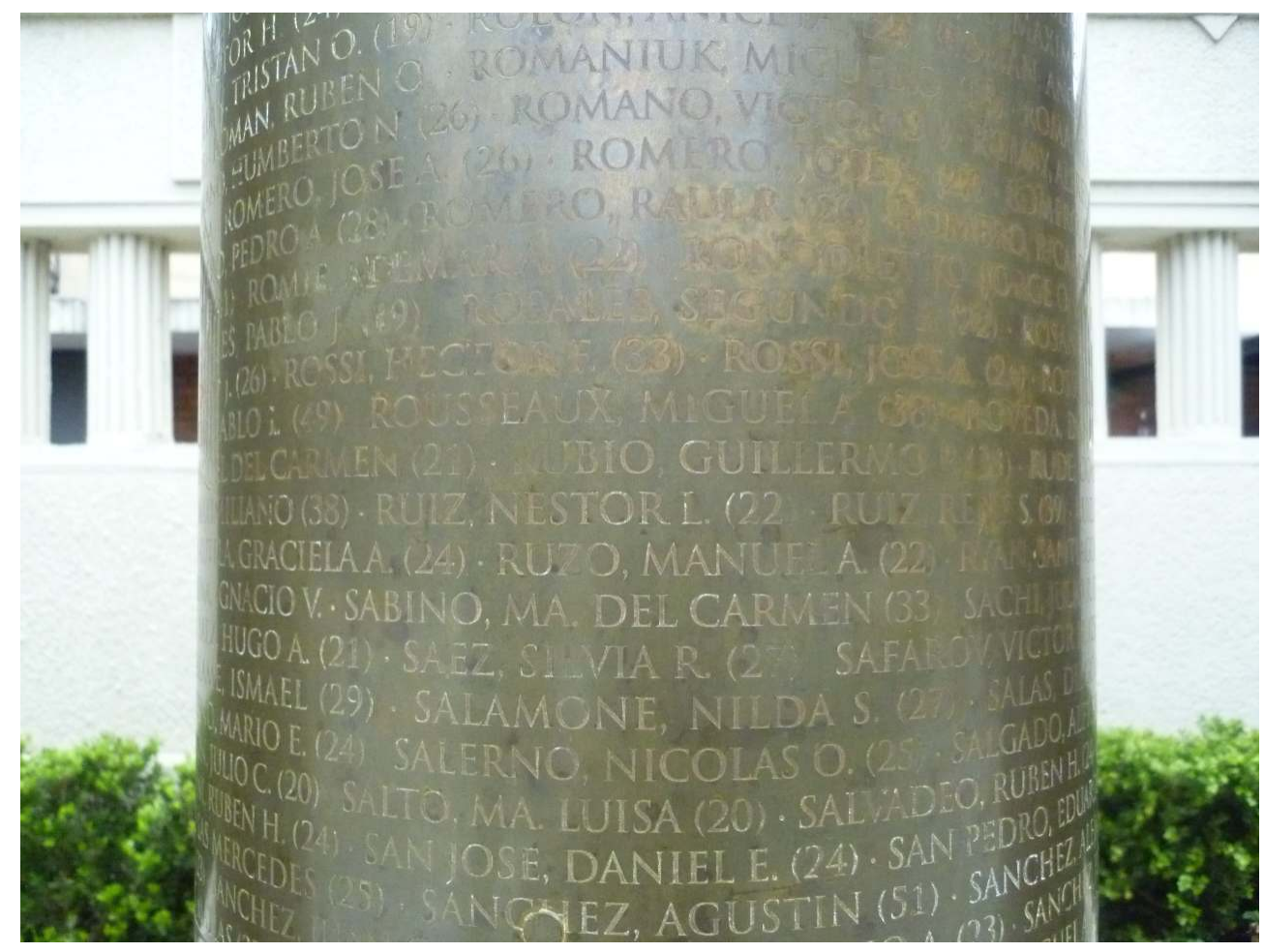

Museo de la Memoria. Rosario

Foto : Andrea Giunta

Un conjunto de columnas giratorias, de metal, llevan inscriptos los nombres de los desaparecidos, los mismos que se encuentran en el Memorial del Parque de la memoria. Se pueden leer, se pueden recorrer girando con las manos los diez cilindros de metal. El público adquiere así un contacto mediado por el relato de la institución y por la interpretación que los artistas proponen del pasado : desde la evocación de los hechos de violencia en América Latina hasta los testimonios de sobrevivientes, militantes, familiares; el mapa de centros clandestinos; las rondas de las Madres como símbolo de resistencia o la lista de las víctimas del terrorismo de Estado. ${ }^{26} \mathrm{El}$ arte contemporáneo se integra como una solución visual para narrar la historia, "proponiendo un lugar de interpretaciones en el que el público participa a través de sus sentidos y su reflexión". Las obras compactan la tensión histórica y estética que el museo buscan aproximar al público. La decisión crucial en este caso radica en mostrar el archivo desde la interpretación del artista. El museo en su totalidad es un espacio meditativo en el que la estética moldea el dato histórico ; frente a la obra, el público conoce, reflexiona, siente. El museo desplaza así la separación entre una zona documental, en la que el archivo se ordena con la apariencia de objetividad, y otra de reflexión que integra principios estéticos. Esta decisión puede interpretarse, en principio, como la crítica a la objetividad y a la transparencia del archivo; el cuestionamiento de toda posibilidad de aproximarse a la verdad del pasado. El caso permite pensar sobre el significado de la eliminación de cronologías o secuencias documentales que permitan reconstruir la facticidad de los años de la dictadura. La obra de arte contemporáneo abre el archivo, el documento, y lo expone a interpretaciones más porosas que el relato único, unidireccional que pautaría un guión ordenado desde una cronología. Permite, también, enfocarse en núcleos 
temáticos consensuados que evitan el desacuerdo que todo guión vuelve evidente entre los organismos de derechos humanos a la hora de establecer cuáles fueron los hechos significativos del pasado, cómo deben ordenarse, cuáles son los límites desde los que se puede mostrar, ordenar y narrar ese período de la historia. El pasado, se sostiene desde esta museografía, no puede circunscribirse a una historia ; se aborda desde historias que incluyen el documento pero que al mismo tiempo lo articulan en un mecanismo perceptual-emocional.

El Parque de la Memoria también incorpora el arte contemporáneo. En el Parque la sala Pays incluye exposiciones de artistas argentinos e internacionales vinculadas a temas de dictadura, violencia, memoria. En 2013 se presentó una instalación de siete video instalaciones de Bill Viola, Punto de partida, en la que se actuaba, una y otra vez, desde distintas imágenes, la idea de la partida, el momento doloroso de la separación. En el film se ven personas que esperan en una línea y en un lento adiós, con movimientos ralentizados, se aproximan, una tras otra, a la cámara, a alguien o a algo de lo que parecen despedirse con dolor. ${ }^{27} \mathrm{El}$ parque que rodea al Monumento también reúne esculturas seleccionadas a partir de un concurso internacional. ${ }^{28}$ Entre ellas el conjunto realizado por el Grupo de Arte Callejero (GAC), una instalación de 54 carteles que desarrolla una señalización del parque que utiliza el lenguaje urbano para proponer un relato de los antecedentes y las consecuencias de la última dictadura. 0 , en un lenguaje más poético, la obra $A$ los derechos humanos, de León Ferrari, una escultura de cientos de varas de acero que vibra con el viento que proviene del río y que da lugar a conciertos en el parque.

Imagen 10. León Ferrari. A los derechos humanos. 2011.

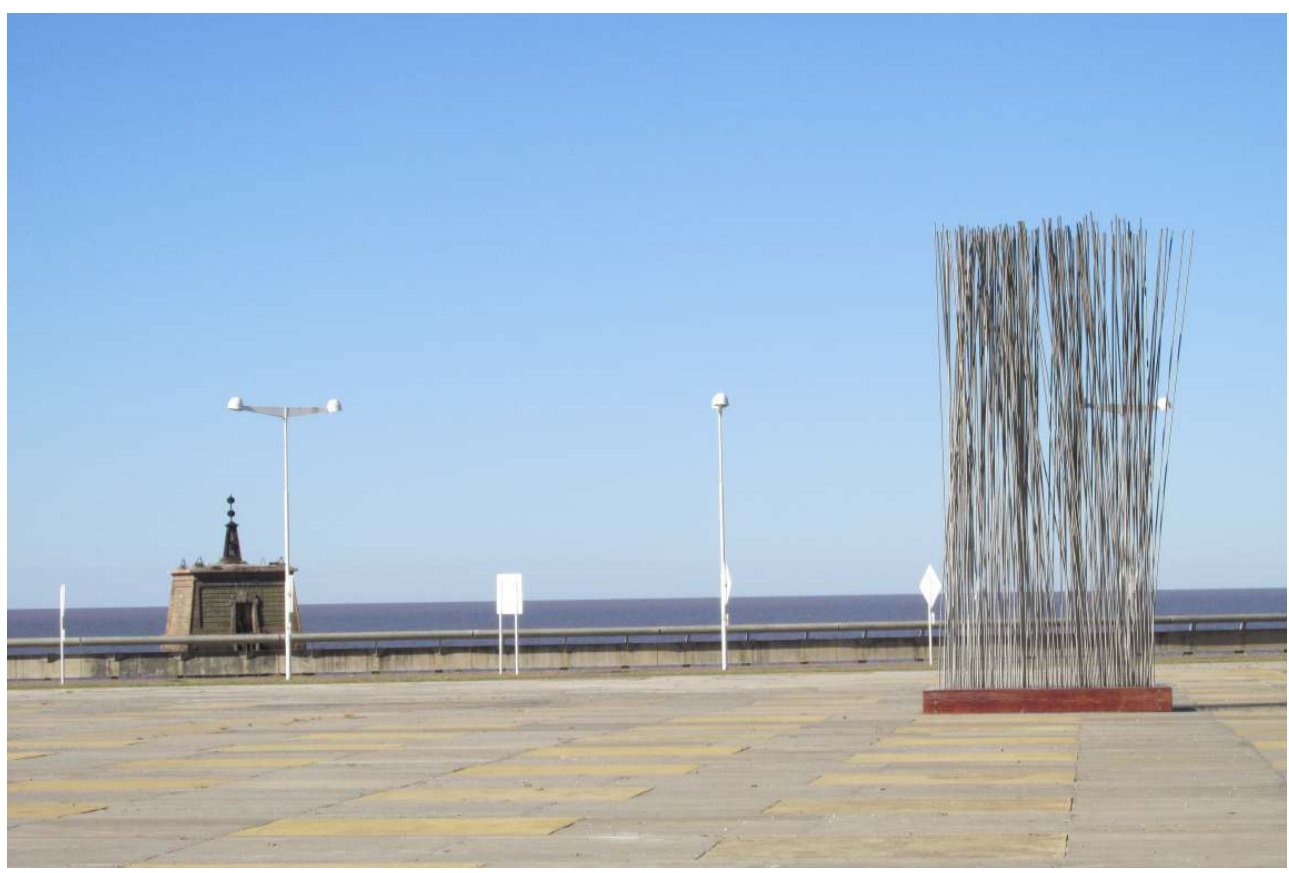

Parque de la Memoria. Buenos Aires. 16 de abril de 2014.

Foto : Andrea Giunta

Estas museografías plantean una pregunta general acerca de las decisiones que han tomado acerca de cómo producir la relación entre la exposición de los crímenes de la dictadura y el público. Plantean interrogantes sobre la estetización de la violencia, sobre 
el estatuto de los documentos, sobre las estrategias elaboradas para narrar sin clausurar la historia. Reponer el pasado desde instrumentos que lo evocan, que impulsan emociones, que rearman desde el archivo experiencias intelectuales y sensoriales, activa también la pregunta acerca de lo irresuelto de la historia, acerca de la dificultad no tanto por consensuar un relato que unifique en un formato lineal el tiempo pasado, sino que siquiera permita comprender su multiplicidad, las agendas que estaban en juego, las decisiones que se tomaron, los hechos que tenían visibilidad pública y aquellos que pueden deducirse de los archivos. Los museos ponen de manifiesto la tensión entre historia y memoria, la dificultad de abordar, desde archivos y registros una historia compleja, que active las contradicciones y que, de ningun modo actúe como explicación causal de los crímenes de lesa humanidad cometidos por el Estado de la dictadura. ${ }^{29} \mathrm{Se}$ trata de establecer espacios para la reflexión crítica sobre el pasado. Al mismo tiempo, la existencia de una política de la memoria solventada desde el Estado, la organización de exposiciones en las que se presentan nuevos archivos u obras de arte contemporáneo, contribuyen a que la dictadura y el plan de extermino que instrumentó no sean borrados de la cultura contemporánea integrando en ella las políticas de la memoria articuladas desde las imágenes. La existencia de un arte de la memoria es la prueba del fracaso del plan que la dictadura elaboró para eliminar el pensamiento crítico. ${ }^{30}$

La misión de los museos de la memoria en la Argentina y la concepción de sus guiones curatoriales buscan gestar experiencias distintas que vinculen documentos, relatos y dispositivos emocionales articulados desde el espacio y desde las obras de arte contemporáneo. Su propósito apunta a la transformación de la conciencia ciudadana. Quien no sabía, ahora sabe. Quien no sentía, ahora siente.

\section{El arte de la memoria}

El arte contemporáneo explora insistentemente las relaciones entre representación y memoria. ¿Puede (debe) el arte ayudarnos a rememorar la violencia ? ¿Cuál es la función de esas obras, de esas imágenes, de los monumentos, arquitecturas e instalaciones que se formulan como observatorios del pasado? ¿Cuál es su estatuto epistemológico?, podríamos preguntarnos siguiendo a Didi-Huberman (Didi-Huberman, 2004 : 97).

Los museos y memoriales apuntan a convocar emocionalmente el pasado a fin de evitar su clausura. En este sentido pueden entenderse como una respuesta al trauma, como una operación de elaboración ("working through") o repetición ("acting out") emocional que señalan la diferencia entre duelo y melancolía según la denominación que Dominick LaCapra propone a partir de la diferenciación freudiana. La repetición puede ser inevitable para los sobrevivientes, pero en el caso de los testigos de segunda generación la experiencia va de la repetición a la elaboración (LaCapra 2001 : 90). Desde esta perspectiva la memoria es una forma de distancia crítica respecto del pasado. Permite que lo impensable sea abordado desde una perspectiva crítica. Los museos de la memoria son espacios de conocimiento y de experiencias que hacen posibles distintas formas de elaboración del pasado en lugar de simplemente repetirlo. Invitan a reflexionar críticamente sobre el pasado reciente desde un registro que actúa aspectos emocionales. Conmover para conocer. Es funcional a esta noción la que Marianne Hirsh utiliza para referirse a la memoria de los hijos de los sobrevivientes, postmemory, a fin de captar la distancia entre quienes fueron testigos directos de los años de la dictadura, en el caso argentino y latinoamericano, y la familia y la sociedad que les sucede. Remite a la 
experiencia de quienes crecen en contacto con las narrativas que preceden, incluso, a su nacimiento. Poseedores de una memoria de segunda generación, con huecos, en la que las fotografías actúan como vínculo entre generaciones, como sucede con las fotografías de Germano. Aún cuando Hirsh desarrolla esta noción en relación con los hijos de los sobrevivientes del Holocausto, considera que puede utilizarse para referirse a los recuerdos de otras segundas generaciones que expresen el trauma colectivo generado por esos eventos y experiencias. Las acciones de la agrupación H.I.J.O.S. se vinculan al sentido más estricto de la noción de postmemory. Pero en una comprensión amplia podemos considerar también las obras de arte vinculadas a la memoria, los memoriales y museos, que activan esa memoria de segunda generación en un sentido social expandido. Los recuerdos y testimonios de los protagonistas se despliegan en múltiples formatos a fin de crear nuevas formas de articular la memoria social.

La contracara de este programa utópico frente al poder del recuerdo es su “industrialización" (Bilbija y Payne, 2011). La mención de la multiplicación incesante de sitios de la memoria y su vinculación a la redefinición de las nuevas democracias latinoamericanas (Argentina, Brasil, Chile, Perú, Uruguay) en función de la rememoración y monumentalización de pasados impregnados por la violencia de esos mismos Estados a los que las políticas de derechos humanos contribuyen a redefinir, apunta a señalar estos efectos. Entre ellos la hipertrofia de la historia, a la que remite Nietzsche y que hoy podemos vincular a la memoria, frente a la cual hacía un llamado al olvido creativo, según nos recuerda Andreas Huyssen (Huyssen, 2003). Una opción que el propio Huyssen desecha como indeseable e irrealista en un tiempo en el que no puede dejarse de lado la amenaza de la amnesia social. Las redefinidas democracias latinoamericanas no han optado por el olvido, han exacerbado el recuerdo, han hecho de la memoria y del pasado parte de su agenda política. Lo que puede ser leído como una crítica tiene su contracara: ese pasado constituye su capital político justamente porque sectores de la sociedad se resisten a cerrarlo. Redundantes y al mismo tiempo opacas, tensadas entre la literalidad y el desvío, las imágenes del arte y las estrategias en torno a la organización de la cultura contemporánea han propuesto formas de rediseñar el presente a partir de una confrontación cotidiana con el pasado.

\section{BIBLIOGRAFÍA}

BILBIJA Ksenija y PAYNE Leigh A. (Eds.), Accounting for Violence. Marketing Memory in Latin America, Durham and London, Duke University Press, 2011.

BUTLER Judith, "Violence, Mourning, Politics," in Emotions. A Cultural Studies Reader, Jennifer HARDING and E. Deidre PRIBRAM (Eds.), London and New York, Routledge, 2009.

CAIA, Centro Argentino de Investigadores de Artes, Ciudad/Campo en las artes en Argentina y Latinoamérica, Buenos Aires, CAIA, 1991.

CAIA, Centro Argentino de Investigadores de Artes, Arte y poder, Buenos Aires, CAIA, 1993. 
CALVEIRo Pilar, Poder y desaparición. Los campos de concentración en Argentina, Buenos Aires, Colihue, 2004.

CALVEIRo Pilar, Política y/o violencia. Una aproximación a la guerrilla en los años setenta, Buenos Aires, Editorial Norma, 2006.(reedicion de Siglo XXI, 2013)

CALVEIRO Pilar, Violencias de Estado. La guerra antiterrorista y la guerra contra el crimen como medios de control global, Buenos Aires, Siglo XXI, 2012.

CERISOLA Igor (Roberto Amigo), “Este año se cumple una década de "El Siluetazo", in La Maga, entrevista de Hernán ALMEJEIRAS, Buenos Aires, 1993, pp. 10-11.

DIDI-HUBERMAN George, Imágenes pese a todo. Memoria visual del Holocausto, Barcelona, Paidós, 2004.

GIUNTA Andrea, "Cuerpos de la historia: Vanguardia, política y violencia en el arte argentino contemporáneo", in Cantos Paralelos, RAMÍREZ, Mari Carmen (Ed.), AUSTIN, Jack S. Blanton Museum of Art, The University of Texas at Austin, 1999.

GIUNTA Andrea, (editora y autora), León Ferrari. Retrospectiva, 1954-2004, Buenos Aires, Centro Cultural Recoleta-MALBA, 2004.

GIUNTA Andrea, "Politics of Representation. Art \& Human Rights", in After Thruth, Hemispheric 7.2, 2010, http://hemisphericinstitute.org/hemi/en/e-misferica-72/giunta (consultado el 2-1-2014) HIRSCH Marianne, Family Frames. Fotography, narrative and postmemory, Cambridge and London, Harvard University Press, 1997.

HUYSSEN Andreas, En busca del futuro perdido. Cultura y memoria en tiempos de globalización, Buenos Aires, Fondo de Cultura Económica, 2007.

JACOBY Roberto, “Las herejías de León Ferrari”, in Crisis, Buenos Aires, 1987. Parcialmente reproducido en Andrea GIUNTA (Ed.), op. cit., 1987, pp. 164 y 169. Online en http:// leonferrari.com.ar/files/leon-ferrari---cronologia.pdf (consultado el 2-1-2014)

LACAPRA Dominick, Writing History, Writing Trauma, Baltimore, John Hopkins University Press, 2001.

LAEUCHLI Samuel, Religion and Art in Conflict, Philadelphia, Fortress Press, 1980.

LEVINAS Emmanuel, Humanismo del otro hombre, México, Siglo XXI, 1993.

LONGONI Ana y BRUZzone Gustavo (Ed.), El Siluetazo, Buenos Aires, Adriana Hidalgo, 2008.

Nunca Más. Informe de la Comisión Nacional sobre la desaparición de personas (1984), Buenos Aires, Editorial Universitaria de Buenos Aires.

QUIETo Lucila, Arqueología de la ausencia, Buenos Aires, Casa Nova Editores, 2011.

QUIETo Lucila, “Entrevista a Lucila Quieto", Centro Cultural de la Memoria Haroldo Conti, Buenos Aires, 2013, http://conti.derhuman.jus.gov.ar/2013/04/noticias-entrevista-lucila-quieto.shtml (consultado el 2-1-2014)

QUIGLEY Sarah, “Holocaust Memorial : Architect Peter Eisenman, Berlin, 2005; http://www.warmemorial.net/Holocaust-Memorial-Architect-Peter-Eisenman,-Berlin-2005-2.66 [acceso : 26.4.2013]

RAFECAS Daniel, Historia de la solución final. Una indagación de las etapas que llevaron al exterminio de los judíos europeos, Buenos Aires, Siglo XXI, 2012.

sото Arturo Pascual (Ed.), Arte y violencia, México, IIES, 1995. 


\section{NOTAS}

1. La C.O.N.A.D.E.P., Comisión Nacional sobre la Desaparición de Personas, fue creada por el presidente de la Argentina Raúl Alfonsín (1983-1989) el 15 de diciembre de 1983, con el propósito de las violaciones a los derechos humanos durante el Terrorismo de Estado (1976-1983). En el informe final se registraron 8.961 desaparecidos y 380 centros clandestinos de detención. El juicio se realizó en 1985, ordenado por el presidente Alfonsín. Fueron condenados a cumplir distintas sentencias Jorge Rafael Videla, Emilio Eduardo Massera, Roberto Eduardo Viola, Armando Lambruschini y Orlando Ramón Agosti.

2. El universo de imágenes ligadas a la última dictadura es muy extenso. Los casos que abordo en este ensayo no responden a registros periodísticos. Fueron imágenes realizadas con el propósito de abarcar texturas ausentes en los archivos existentes. Aunque fueron concebidas por artistas no fueron pensadas para actuar necesariamente en el mundo del arte. Sin embargo, muchas se han integrado a exhibiciones realizadas en el contexto de una museografía que amplía el estatuto de la tradicional imagen artística incorporando registros, archivos y publicaciones.

3. Ferrari había realizado otra compilación de noticias relativas a la colaboración de la Iglesia argentina con la dictadura. Este archivo, que también envió por correo desde Buenos Aires a Brasil, se extravió.

4. Ferrari consideraba a la Biblia el fundamento de la violencia en Occidente. En ésta destacaba la amenaza, el castigo y las grandes masacres.

5. Al mismo tiempo que realizaba y reproducía en fotocopias este collage, León Ferrari volvía a realizar dibujos (que había suspendido entre 1964 y 1975) y gestaba sus heliografías. Expuse la serie Nosotros no sabíamos en en la retrospectiva de 2004 en el Centro Cultural Recoleta, sobre una mesa inclinada, a fin de facilitar su lectura. En la pared opuesta se disponían las heliografías, realizadas en Sao Paulo, al mismo tiempo que Ferrari distribuía su archivo de noticias en fotocopias. En el segundo montaje, también en el CCR, en el 30 aniversario del golpe de Estado de 1976, las amplié a tamaño mural. En esta oportunidad, y probablemente como consecuencia de la controversia originada por la Retrospectiva, el CCR no incluyó la difusión de la exposición en los comunicados de prensa. Sobre la obra de León Ferrari ver Andrea Giunta, 2004.

6. Y para articular plataformas y redes que le permitiesen encontrar a su hijo Ariel, desaparecido a comienzos de 1977.

7. El señalamiento no es moral; no implica decir que un modo es correcto y el otro incorrecto. Apunta a señalar programas y regímenes de la imagen diferentes. Aunque sin duda el primer procedimiento está más ligado a lo testimonial, a la historia, las imágenes de Grippo que vamos a abordar permiten aproximarnos al registro de lo decible y a la manera histórica en la que se fueron configurando social y culturalmente las representaciones de la violencia.

8. Con el título "Memorias", el artista Marcelo Brodsky realizó una instalación sobre libros enterrados durante la dictadura. http://sobredicion.wordpress.com/category/dictadura/ (consultado el 2-1-2014)

9. La masacre de Trelew -en la que se asesinaron a 16 presos integrantes de distintas organizaciones armadas el 22 de agosto de 1972- fue una marca significativa en la cultura de esos años. Trelew anticipó la impunidad de un poder represivo que luego se generalizaría.

10. Entrevista de la autora con el artista, agosto de 1993.

11. Y aún después de la dictadura. El caso argentino es elocuente y ejemplificatorio. El 23 de marzo de 1983 la junta militar promulga una ley de auto-amnistía derogada en democracia por el Congreso el 15 de diciembre del mismo año, durante el gobierno de Raúl Alfonsín. En 1985, por orden de Alfonsín, se lleva adelante el juicio que condena a representantes de las juntas militares, constituyendo un juicio sin equivalentes en los otros países latinoamericanos. El 24 de diciembre 
de 1986, el presidente Raúl Alfonsín promulga la ley aprobada por el congreso de Punto Final que estableció la caducidad de la acción penal contra los imputados del delito de desaparición forzada. El 4 de junio de 1987 se dicta la ley de Obediencia Debida que establece que no son punibles los militares que actuaron cumpliendo órdenes. Entre el 7 de octubre de 1989 y el 30 de marzo de 1990, el presidente Carlos Menem (1989-1995 y 1995-1999) firmó decretos que indultaron a más de 1200 personas, civiles y militares. En 2003, durante el gobierno de Néstor Kirchner (2003-2007), el congreso declara la nulidad de las leyes de Punto Final y de Obediencia Debida y luego algunos jueces comenzan a declarar inconstitucionales los indultos. En 2006 la Cámara de Casación Penal, consideró que los indultos concedidos en delitos de lesa humanidad eran inconstitucionales. Desde 2007, durante el gobierno de Cristina Fernández de Kirchner (2007-2011 y 2011-hasta 2015) se llevan adelante distintos juicios sobre violaciones de derechos humanos que se siguen en más diez causas.

12. En el campo de la historia del arte tempranamente fue visibilizado y debatido el estatuto político y estético de El siluetazo. Roberto Amigo fue becado por la Universidad de Buenos Aires para desarrollar una investigación que estuvo inscripta en el Instituto de Teoría e Historia del Arte "Julio E. Payró". Sus avances de investigación se difundieron en conferencias nacionales e internacionales y en estos espacios se debatieron intensamente interpretaciones alternativas. $\mathrm{El}$ hecho de que la UBA concediese una beca en el campo de la historia del arte para investigar sobre una acción estética vinculada al activismo era impensable durante los años de la dictadura. Durante la postdictadura se opera una radical transformación en el campo de los estudios de historia del arte en la Argentina. La vinculación entre la historia del arte, otras disciplinas (literatura, filosofia, sociología) y los emergentes estudios culturales fue central para la ampliación de su tradicional campo de estudio. Un compendio de textos ensayísticos, analíticos y testimoniales puede encontrarse en Longoni y Bruzzone (Ed.) (2008). Para reconstruir las sucesión de publicaciones que acompañaron a estos debates ver las publicaciones de CAIA (1991 y 1995) y IIE (Soto 1995).

13. El colectivo GAS-TAR interviene con una silueta en el piso, la de Dalmiro Flores, asesinado por las fuerzas represivas en la manifestación del 16 de diciembre de 1982. La imagen se reproduce en Arte y violencia (Amigo 1995 : 274) con el mismo epígrafe con el que se incluye en Cantos Paralelos (Giunta 1999 : 157)

14. Analicé este proceso de migración de imágenes en el artículo "Politics of Representation. Art \& Human Rights" (2010).

15. Pueden verse las imágenes en http://www.gustavogermano.com/\#ausencias (consultado el 2-1-2014)

16. Hijos e Hijas por la Identidad y la Justicia contra el Olvido y el Silencio, creada en 1995. Ver http://www.hijos-capital.org.ar/ (consultado el 2-1-2014)

17. Entre 1999 y 2001 realizó 13 tomas o historias que publicó en Lucila Quieto, Arqueología de la ausencia, Buenos Aires, Casa Nova Editores, 2011.

18. Varios intelectuales destacados, como el escritor Günter Grass, demandaron la reevaluación del proyecto por considerarlo opresivo y abstracto. El centro de información que se encuentra debajo fue, en parte, una respuesta a estas objeciones. Eisenman destaca la quietud del monumento y el hecho de que sea el espectador el que tiene que desplazarse. "Pienso que las personas van a comer el almuerzo en los pilares", anticipaba Eisenman. "Estoy seguro que lo van a usar los skateboarders. Las personas danzarán en su superficie. Todo tipo de cosas inesperadas van a suceder." (Quigley, 2005)

19. Proyecto del estudio Baudizzone-Lestard-Varas y de los arquitectos asociados Claudio Ferrari y Daniel Becker.

20. Las diagonales son recurrentes en las arquitecturas de la memoria. Toda la superficie que cubre el Museo de la Memoria y los Derechos Humanos de Santiago de Chile esta atravesada por diagonales; el recorrido del Museo Judío de Berlín (que también tiene diagonales en su exterior) 
nos coloca permanentemente frente a planos desviados y encrucijadas donde el sentido del relato curatorial no es ortogonal ni cronológico. Está marcado por puntos de encuentro y de dispersión. 21. También la luz interviene en muchos museos de la memoria en la composición de ese momento performático transformativo. En el Museo de la Memoria y la Tolerancia de la ciudad de México, a las fotografías del horror de los campos se contrapone un espacio perceptual que evoca una chimenea. Es una caja obscura, casi unipersonal, en la que penetra, desde arriba, una luz mínima del exterior. Un espacio que muta con los cambios de luz y en el que se oye, susurrada, la palabra "libertad". Aquí se activa la distancia entre el documento y la transformación de la conciencia ciudadana a la que el museo, en su conjunto, aspira. Un dispositivo meditativo comparable a aquel en el que culmina el eje del Holocausto en el museo Judío de Berlín : una torre de hormigón, hueca, de sección trapezoidal, iluminada tan solo por la luz que proviene de una rendija superior.

22. Archivo Nacional de la Memoria, Canal Encuentro, Casa de la Militancia-Hijos e Hijas por la Identidad y la Justicia contra el Olvido y el Silencio- H.I.J.O.S., Casa por la identidad, Centro Cultural de la Memoria Haroldo Conti, Centro Internacional de Educación en Derechos Humanos de la UNESCO, Espacio Cultural Nuestros Hijos (EcuNHi) - Asociación Madres de Plaza de Mayo, Familiares de Desaparecidos y Detenidos por Razones Políticas , Iniciativa Latinoamericana para la identificación de Personas Desaparecidas I.L.I.D., Instituto de Políticas Públicas de Derechos Humanos del MERCOSUR, Instituto Espacio para la Memoria-IEM, Madres de Plaza de Mayo Línea Fundadora, Memoria Abierta.

23. Forman parte de su Directorio: Abuelas de Plaza de Mayo I Asamblea Permanente por los Derechos Humanos-APDH | Asociación Madres de Plaza de Mayo | Asociación Buena Memoria | Centro de Estudios Legales y Sociales-CELS $\mid$ Familiares de Desaparecidos y Detenidos por Razones $\underline{\text { Políticas }}$ | Fundación Memoria Histórica y Social | Hijos e Hijas por la Identidad y la Justicia contra el Olvido y el Silencio-H.I.J.O.S. | Herman@s de Desaparecidos por la Verdad y Justicia | Liga Argentina por los Derechos del Hombre-LADH | Madres de Plaza de Mayo Línea Fundadora | Movimiento Ecuménico por los Derechos Humanos-MEDH | Servicio Paz y Justicia-SERPAJ

24. Así era en el momento en el que visité el espacio, en agosto de 2012.

25. Ver http://www.museodelamemoria.gob.ar/page/institucional/id/1/title/Historia-yFundamentos (consultado el 6-2-2014)

26. Los artistas que participan son Dante Taparelli, Norberto Puzzolo, Daniel García, Graciela Sacco, Julieta Hanono, Federico Fernández Salaffia, Lucrecia Moras, Silvio Moriconi, acompañados por equipos de Memoria Abierta y por los arquitectos Alejandra Buzaglo y Gonzalo Conte.

27. Hasta mayo de 2014, además de Viola exhibieron Luis Camnitzer, Graciela Sacco, Dolores Cáceres, RES, Norberto Puzzolo, Eduardo Gil y Carlos Trilnick.

28. Se eligieron 12 proyectos de los 665 presentados. El concurso se realizó en 1999 a partir de una iniciativa apoyada por legisladores de la Ciudad Autonoma de Buenos Aires aprobada en 1998.

29. Tal es la línea que buscan imprimir las objeciones a museografías de la memoria en Perú y en Chile cuando se señala aquello que "no se incluye". En Perú, por ejemplo, en 2009 el gobierno rechazó la donación de dos millones de dólares que Alemania hacía para la construcción de un Museo de los Derechos Humanos. Al mismo tiempo su Ministro de defensa anunciaba la realización de una exposición que completara la vision de Yuyanapaq, documentando el sufrimiento de las Fuerzas Armadas. Ver http://peru21.pe/noticia/253301/gobierno-anuncia-supropia-exposicion-sobre-violencia-terrorista (consultado el 5-2-2014). Yuyanapaq, que en quechua significa "para recordar", es la exposición fotográfica que se presentó en 2003 en Lima. En esta se incluyó un registro documental que acompañó lo reportado en el Informe Final de la Comisión de la Verdad y Reconciliación en Perú, un informe sobre las víctimas de la organización armada Sendero luminoso y de la represión de las fuerzas armadas. En Chile a directora de 
Bibliotecas Archivos y Museos (Dibam), Magdalena Krebs planteó que al museo le faltaba "contextualización", a lo que respondió la directora del Instituto Nacional de Derechos Humanos (INDH), Lorena Fries, sosteniendo que las violaciones de los derechos humanos no se pueden explicar ni contextualizar. http://www.lanacion.cl/debate-por-museo-de-la-memoria-directorade-la-dibam-baja-el-perfil-a-sus-dichos/noticias/2012-06-27/094216.html (consultado el 4-2-2014)

30. Podrían pensarse, como prueba de ese pasado y vigencia de una memoria crítica, los libros de Pilar Calveiro socióloga y es militante montonera radicada en México), tanto los volúmenes centrados en la represión, memoria y militancia revolucionaria de los años setenta $(2004,2006)$ como aquél (2012) en el que aborda en dos conflictos contemporáneos, la guerra contra el crimen y la guerra antiterrorista, las relaciones entre las prácticas represivas de la dictadura y las actuales violaciones de los derechos humanos.

\section{RESÚMENES}

En el arte argentino contemporáneo la pregunta por el pasado (los discursos fundadores de la Nación, el pasado ominoso de la dictadura) es más recurrente que el ideario que busca imaginar o anticipar el futuro. Se revisan iconografías fundadoras del relato nacional y se desarrolla un amplio repertorio de estrategias para hacer de las imágenes formas de meditación, estrategias que contribuyan a evitar la clausura del pasado. El corpus de imágenes es tan amplio que requiere diferenciar sus estrategias y entenderlas no sólo en términos poéticos sino también en su relación con una historia, la de la violación de los derechos humanos en la Argentina, que se ha transformado en los últimos treinta años. En este artículo se analiza una selección de imágenes y de estrategias institucionales vinculadas a la museografía de la memoria desde los años setenta hasta el presente. El propósito es investigar los dispositivos desarrollados por artistas e instituciones no sólo para diseminar información acerca de lo sucedido en los años de la represión (documentos, testimonios, denuncias) sino también para articular sentimientos capaces de producir una experiencia nueva, frente a la obra, en la sala del museo, que resulte, en sí misma, una experiencia para recordar.

Dans l'art argentin contemporain, les interrogations sur le passé, qu'elles portent sur les discours fondateurs de la nation ou sur l'amnésie des années de la dictature, sont plus itératives que celles qui sont tournées vers le futur, pour imaginer ou anticiper celui-ci. On revisite l'iconographie fondatrice $\mathrm{du}$ "grand récit national » et l'on développe toute une gamme de stratégies pour conférer à ces images une fonction de médiation, stratégies qui contribuent à conjurer la clôture du passé. Le corpus d'images est si vaste qu'il importe de bien différencier leurs stratégies et de les comprendre non seulement d'un point de vue poétique, mais aussi en fonction d'une histoire, celle de la violation des droits de l'homme en Argentine, dont la narration s'est elle-même transformée au cours des trente dernières années. On analysera dans cet article une sélection d'images et de stratégies institutionnelles en rapport avec la "muséographie de la mémoire ", des années 1970 à nos jours. L'objectif est de se concentrer sur les dispositifs développés par les artistes et les institutions, non seulement pour diffuser des informations sur ce qui s'est passé pendant les années de la répression (documents, témoignages, plaintes), mais aussi pour susciter des sentiments capables de générer une expérience nouvelle face à l'œuvre, dans la salle du musée, qui soit, en tant que tel, une expérience mémorielle. 
ÍNDICE

Mots-clés: Argentine, dictature, mémoire, droits de l'homme, art contemporain, art latinoamericain, musées

Palabras claves: Argentina, dictadura, memoria, derechos humanos, arte contemporain, arte latinoamericano, museos

\section{AUTOR}

ANDREA GIUNTA

CONICET / Universidad de Buenos Aires / University of Texas at Austin 